
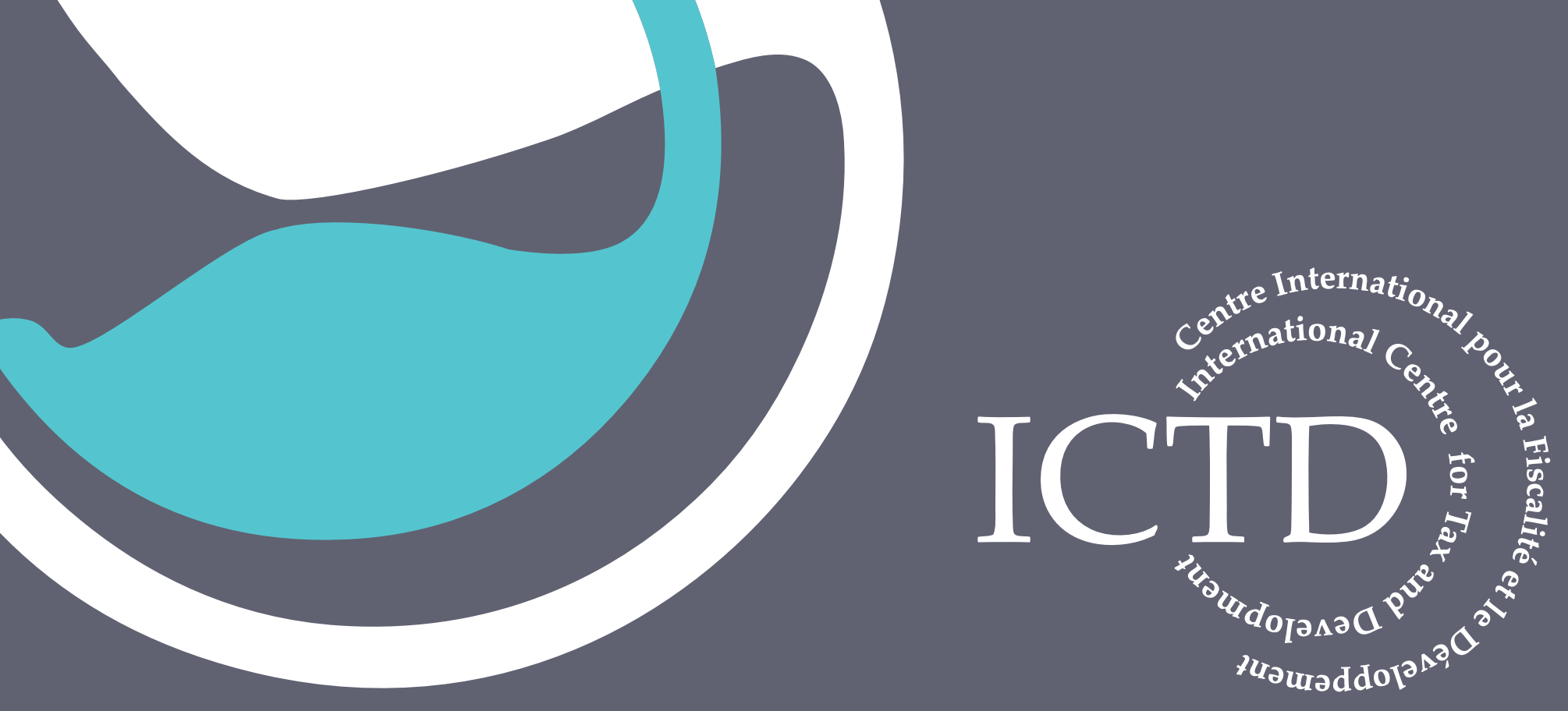

Working Paper 24

\title{
Electoral Competitiveness, Political Budget Cycles and Taxation in Developing Countries
}

Wilson Prichard

September 2014 
ICTD Working Paper 24

Electoral Competitiveness, Political

Budget Cycles and Taxation in Developing

Countries

Wilson Prichard

September 2014 
Electoral Competitiveness, Political Budget Cycles and Taxation in Developing Countries Wilson Prichard

ICTD Working Paper 24

First published by the Institute of Development Studies in September 2014

(C) Institute of Development Studies 2014

ISBN: 978-1-78118-191-1

A catalogue record for this publication is available from the British Library.

All rights reserved. Reproduction, copy, transmission, or translation of any part of this publication may

be made only under the following conditions:

- with the prior permission of the publisher; or

- with a licence from the Copyright Licensing Agency Ltd., 90 Tottenham Court Road, London W1P 9HE, UK,

or from another national licensing agency; or

- under the terms set out below.

This publication is copyright, but may be reproduced by any method without fee for teaching or nonprofit purposes, but not for resale. Formal permission is required for all such uses, but normally will be granted immediately. For copying in any other circumstances, or for reuse in other publications, or for translation or adaptation, prior written permission must be obtained from the publisher and a fee may be payable.

Available from:

The International Centre for Tax and Development

at the Institute of Development Studies,

Brighton BN1 9RE, UK

Tel: +44 (0) 1273606261 Fax: +44 (0) 1273621202

E-mail: info@ictd.ac.uk

Web: www.ictd/en/publications 


\title{
Electoral Competitiveness, Political Budget Cycles and Taxation in Developing Countries
}

\author{
Wilson Prichard
}

\section{Summary}

Despite significant evidence of 'political budget cycles' affecting public expenditure, studies of the impact of elections on tax collection have reached mixed conclusions. Drawing on significantly improved government revenue data, this paper finds, contrary to earlier research, that when we focus on all executive elections in developing countries there is no significant effect on levels of tax collection. Instead, the impact of elections on tax collection is conditional on elections being competitive, with competitive elections resulting in a negative impact on pre-election tax collection, split relatively evenly between direct and indirect taxes. The magnitude of the effect is large, reaching as much as 0.5 per cent of GDP in some specifications, and has important implications for understanding the incentive effects of elections and the connections between elections and effective governance.

Keywords: political budget cycles; fiscal policy; taxation; political economy.

Wilson Prichard is Assistant Professor in Political Science and Global Affairs at the University of Toronto, and Research Co-Director of the International Centre for Tax and Development. 


\section{Contents}

Summary 3

Acknowledgements 6

Acronyms $\quad 6$

Introduction $\quad 7$

$1 \quad$ Taxation and political budget cycles in developing countries 9

2 Hypotheses 11

$3 \quad$ Data and variables $\quad 13$

$\begin{array}{lll}4 & \text { Empirical strategy } & 16\end{array}$

$\begin{array}{lll}5 & \text { Results } & 17\end{array}$

$6 \quad$ Robustness checks 22

7 Discussion $\quad 29$

8 Conclusions $\quad 31$

$\begin{array}{ll}\text { Appendix } & 32\end{array}$

$\begin{array}{ll}\text { References } & 40\end{array}$

Tables

Table 1

Table 2

Table 3

Table 4

Table $5 a$

Correlations between alternative election measures 15

Effect of different election types on tax revenue - fixed effects 18

Effect of different election types on tax revenue - Sys-GMM 19

Effect of elections on direct and indirect tax revenue 21

Robustness checks: re-estimating results using alternative definitions of competitiveness 23

Table 5b Robustness checks: re-estimating key results with alternative measures of competitiveness

Table 6 Robustness checks: re-estimating 'free and fair' results with alternative election datasets $\quad 25$

Table $7 \quad$ Robustness checks: re-estimating results using only central government revenue data $\quad 26$

Table $8 \quad$ Robustness checks: effect of competitive elections using different definitions of 'effective' election year 28

Table A1 Robustness checks: re-estimating key results including all countries 32

Table A2 Robustness checks: re-estimating key results including all non-resource countries

Table A3 Robustness checks: re-estimating key results including all non-resource developing countries 
Table A4 Robustness checks: re-estimating key results including all low-income countries

Table A5 Robustness checks: re-estimating key results using same year definition of elections

Table A6 Robustness checks: re-estimating key results using E6 definition of elections

Table A7 Robustness checks: re-estimating key results using E4 definition of elections

Table A8 Robustness checks: re-estimating key results using E3 definition of elections 


\section{Acknowledgements}

Thanks to the ICTD for the dataset on which this work is based, to the two Working Paper reviewers for valuable comments, and to Paola Salardi for invaluable support in framing and refining the econometric analysis.

\section{Acronyms}

$\begin{array}{ll}\text { DPI } & \text { Database of Political Institutions } \\ \text { GDP } & \text { Gross Domestic Product } \\ \text { GFS } & \text { Government Finance Statistics } \\ \text { GMM } & \text { Generalised Method of Moments } \\ \text { GRD } & \text { Government Revenue Dataset } \\ \text { ICTD } & \text { International Centre for Tax and Development } \\ \text { IMF } & \text { International Monetary Fund } \\ \text { NELDA } & \text { National Elections Across Democracy and Autocracy } \\ \text { OECD } & \text { Organisation for Economic Co-operation and Development } \\ \text { PRIO } & \text { Peace Research Institute Oslo } \\ \text { QED } & \text { Quality of Elections Database } \\ \text { VAT } & \text { Value Added Tax } \\ \text { WDI } & \text { World Development Indicators }\end{array}$




\section{Introduction}

There is a long-established research tradition exploring the effect of elections on short-term fiscal policymaking. Based on theories of opportunistic political budget cycles, these studies predict expanded public spending and reduced taxation in advance of elections, as opportunistic governments seek to secure political support among voters with short time horizons or limited information (Drazen 2001). Recent literature has, in turn, increasingly focused on the existence of conditional political budget cycles, with different institutional environments or electoral characteristics shaping political incentives in distinct ways (de Haan and Klomp 2013). These studies have increasingly focused on developing countries, where weaker institutions and less established democratic traditions predict greater scope for pre-election policy manipulation.

While studies of political budget cycles are narrowly about the fiscal impact of elections, their importance lies at least equally in their ability to offer broader insights into the functioning of democracy. These studies offer direct evidence of whether elections lead political leaders to adopt short-term policy measures in an effort to secure political support. They thus inform broader debates about the potential downside of elections for economic management (Block 2002). Of even greater interest, these studies can offer insights into how the political incentives generated by elections vary in response to institutional factors, or the particular characteristics of individual elections. For example, whether political budget cycles exist, or not, in diverse contexts can reveal differences in the incentives generated by different types of electoral systems (de Haan and Klomp 2013), or in the incentives generated by elections that vary in the extent of political competition or political freedom (Block et al. 2003; Efthyvoulou 2012; Aidt et al. 2011). The impact of elections on political incentives is notoriously difficult to study, making studies of political budget cycles a valuable source of insight into the broader development impact of elections (Chauvet and Collier 2009).

Existing evidence suggests that political budget cycles are particularly pronounced in developing countries, where democratic institutions are often relatively weak. This research has highlighted the vulnerability of elections in weak democracies to short-term policy manipulation, while highlighting the potential short-term costs of elections for effective policy management (Brender and Drazen 2005; Block 2002; Block et al. 2003). However, existing research from developing countries has failed to exploit fully the insights to be found in studies of political budget cycles in two major respects. First, most studies have focused primarily on the expenditure side of the budget, while paying much less attention to tax collection. Second, existing studies have failed to exploit fully what political budget cycles can reveal about the political incentives yielded by different types of elections - that is, for example, whether more competitive, or more 'free and fair', elections affect political incentives in fundamentally different ways than less contested elections. This paper seeks to fill these two gaps.

While most existing studies have focused on the effect of elections on public expenditure, the effect on tax collection may be substantively more important and tell us more about the functioning of democracy in low-income countries. Short-term increases in public spending are relatively easily financed through borrowing, and in many (though not all) cases those spending increases can be curtailed following elections. By contrast, reductions in tax collection create the same fiscal deficit, but may be less visible to taxpayers and can only be achieved through either a difficult-to-reverse reduction in rates, or, more likely, through reducing the quality of tax enforcement. The latter risks the politicisation of national tax agencies, with potential consequences for long-term statebuilding. Precisely because the potential costs of undermining the revenue base are comparatively high, evidence that governments have reduced tax collection prior to elections may offer particularly significant insights into the political incentives generated by elections. Indeed, most studies that have 
considered the impact of elections on both expenditure and revenue have found a significant effect on the former but no effect on the latter (e.g. Brender and Drazen 2005). However, Erhart (2013) has recently reported a negative and significant impact of elections on tax collection, thus prompting further investigation here.

There is equally an opportunity to exploit more fully information about political budget cycles to understand better the political incentives generated by developing country elections. To date, studies in developing countries have largely focused on capturing the institutional contexts in which short-term fiscal manipulation is most likely. As expected, they have found that such manipulation (primarily on the expenditure side of the budget) is more common where elections are relatively new and the institutional environment comparatively weak (Brender and Drazen 2005; Block 2002; Erhart 2013). By contrast, they have largely failed to ask whether the characteristics of elections themselves - that is, how competitive or free and fair they are - affect the political incentives that elections generate. While both Block et al. (2003) and Chauvet and Collier (2009) explore this question to some extent, both adopt very minimalist definitions of electoral competition. ${ }^{1}$ They thus offer insights into the importance of multiparty competition and basic electoral freedoms, but do not tell us anything about whether political incentives differ substantially as multiparty elections become more 'high quality' or tightly contested.

Against this background, this study employs markedly improved cross-country data on tax collection in developing countries - drawn from the newly-created International Centre for Tax and Development Government Revenue Dataset (ICTD GRD) - in order to test the relationship between elections and tax collection in developing countries. Central to the paper is an effort to test systematically a wide range of alternative hypotheses about the impact of distinct types of elections: all elections, contested elections, free and fair elections, first elections in new democracies, transition elections resulting in a victory by the opposition, and, finally, competitive elections in which the opposition wins at least 40 per cent of seats in government.

The results are strikingly clear-cut. There is no evidence that elections in general affect tax collection, nor that contested multiparty elections do so. There is similarly no consistent evidence that free and fair elections, first elections or transition elections have a significant effect on tax collection. However, there is consistent evidence that competitive elections have a significant and substantial negative impact on pre-electoral tax collection, amounting to an average of 0.3 per cent to 0.5 per cent of GDP. Strikingly, this effect grows stronger as the definition of competitiveness becomes more restrictive, while disappearing when adopting the type of minimalist definition of competitiveness adopted by Block et al. (2003) and Chauvet and Collier (2009).

The importance of this finding lies in part in its immediate implications for policy management: elections can lead to pre-electoral reductions in tax collection, and there appears to be value in countervailing measures to mitigate this risk. However, the greater importance of the findings lies in what they tell us about elections in developing countries. It is a foundational feature of democratic theory that elections should have a larger effect on the political incentives of governments when they are competitive - it is only then that incumbent governments face a genuine threat of losing office (Kitschelt and Wilkinson 2007). However, this intuition is difficult to test empirically (Gordon and Huber 2007), and the results presented here are among the clearest illustrations of the importance of electoral

Block et al. (2003) simply distinguish between single party elections (uncompetitive) and multiparty elections (competitive). Chauvet and Collier (2009) go further, focusing on a combination of basic electoral freedoms and opposition parties winning at least $25 \%$ of the vote. However, winning $25 \%$ of the vote is still far from constituting a significant electoral threat, and thus likely fails to capture a significant dimension of the concept of competitiveness. 
competitiveness in shaping the political incentives generated by elections in developing countries. $^{2}$

Of course, the findings reported here focus specifically on short-term political incentives and short-term reductions in tax collection resulting from greater electoral competitiveness are likely an undesirable outcome from a social perspective. However, the results have implications for broader studies of the development impact of elections. If competitive elections have a larger effect on short-term political incentives, the same is very likely to be true of long-term political incentives as well. Whereas most studies of the development impact of elections have focused on elections in general (e.g. Stasavage 2005; Harding and Stasavage 2014), the results here imply the need for more systematic attention to the role of electoral competitiveness in conditioning the effect of elections on political incentives and, by extension, development outcomes (Chauvet and Collier 2009).

The paper proceeds as follows. The first section provides a brief review of the literature. Section 2 specifies the hypotheses tested by the paper. Section 3 provides an overview of the data and variables used in the analysis. Section 4 presents the empirical strategy, and Section 5 the key results. Section 6 presents robustness tests, Section 7 discusses the key findings and Section 8 concludes.

\section{Taxation and political budget cycles in developing countries}

Researchers have long been interested in the possibility that elections may lead governments to alter the pattern of pre-election expenditure and taxation in an effort to secure electoral support (Drazen 2001). The intuition behind opportunistic political budget cycles is straightforward: if voters are relatively short-sighted or have limited information, then short-term increases in public spending or decreases in tax collection could be effective strategies for increasing government popularity (Norhaus 1975; Rogoff and Sibert 1988; Persson and Tabellini 2002).

While early research focused on the average effect of elections on fiscal variables, more recent research has turned attention to the possibility of 'conditional political budget cycles', with the existence or absence of political budget cycles dependent on particular features of the institutional environment, or particular features of different elections (de Haan and Klomp 2013). This literature has stressed that many institutional factors expected to facilitate political budget cycles - including weak checks and balances and limited experience with democracy - are common to many developing countries, with corresponding evidence that political budget cycles are more significant in the developing world (de Haan and Klomp 2013; Shi and Svensson 2006; Brender and Drazen 2005).

While there is relatively extensive evidence of the existence of political budget cycles in developing countries, the vast majority of this research has focused on public expenditure or the overall size of the fiscal deficit. By contrast, the impact of elections on tax collection has more often been overlooked. This in part reflects greater ambiguity about the expected impact of elections on tax collection. On one hand, reductions in tax collection may be politically popular. On the other hand, decreases in tax collection may be less visible to taxpayers, may be more costly from the perspective of governments, and may necessitate corresponding decreases in public spending if there is a limit to the capacity of the

In developed countries Efthyvoulou (2012) and Aidt et al. (2011) have similarly found that political budget cycles are larger where elections are more competitive. 
government to run fiscal deficits. Consistent with this story, much of the literature finds that political budget cycles in developing countries are driven overwhelmingly by changes in expenditure rather than changes in taxation (Block 2002; Brender and Drazen 2005; Schuknecht 2000).

In a more recent study, however, Erhart (2013) focuses explicitly on the impact of elections on taxation, and reports two significant findings. First, she reports that elections as a group have a negative and significant effect on pre-election tax collection, amounting to about 0.2 per cent of GDP. She suggests that this decline may in part result from formal policy changes, but is equally likely to result from politically-motivated laxity in enforcement. Second, and more novel, she finds that this impact varies by tax type, with elections having a negative impact only on indirect tax collection. She follows the logic of earlier work by Drazen and Eslava (2010) in attributing this pattern to the fact that indirect taxes have a much broader incidence than direct taxes, and are thus expected to benefit a much broader group of potential voters.

However, there are reasons to question the theoretical basis for this focus on indirect taxes. This focus implicitly assumes that taxpayers are aware of their tax liabilities, and that political leaders seek to secure political support through direct policy appeals to a broad base of potential voters. Both assumptions may not hold in many developing countries. Political systems are often heavily patronage-based, relying on the ability of governments to deliver comparatively targeted benefits to politically influential individuals and groups (Kitschelt and Wilkinson 2007). Meanwhile, direct taxes are frequently more visible and politically salient than indirect taxes, with many taxpayers only weakly aware of the extent of the indirect tax burden (Bird and Zolt 2005; Prichard 2010). ${ }^{3}$ For both reasons, rational governments may in fact target short-term reductions in the collection of direct taxes as they may be more immediately visible to taxpayers, while garnering the support of politically-important actors. By contrast, reductions in indirect taxes may be viewed as inefficient owing to their lack of visibility, and the fact that they do not correspond to the logic of patronage-based electoral strategies.

More widely explored in the literature is the possibility that the extent of political budget cycles may be conditional on particular features of the institutional environment, or of elections themselves (de Hann and Klomp 2013). Block et al. (2003) propose that political budget cycles will be more significant where elections are more competitive, as electoral competitiveness should increase pressure on incumbent governments. They find that competitive elections have a negative impact on the overall fiscal balance. However, they define competitiveness very loosely, as the existence of multiparty competition. They make no reference to the extent of contestation - defined, for example, as the margin of electoral victory - while they do not focus on the impact on taxation in particular.

Both Block et al. (2003) and Brender and Drazen (2005) consider the possibility that political budget cycles may be more pronounced in 'new democracies', though with mixed results. Brender and Drazen (2005) find larger pre-electoral increases in public expenditure in new democracies, which they define to include the first four elections after a democratic transition. However, they find an insignificant effect on tax collection. Block et al. (2003) focus more narrowly on first or 'founding' elections, but do not consistently find a distinct effect of first elections on the fiscal balance. Finally, Erhart (2013) and others consider the possibility that

While the tax literature has tended to argue that indirect taxes are less visible than direct taxes, this is not, of course, universal and has been challenged elsewhere, as sales taxes and value added tax (VAT) can become heavily politicised (Martin and Gabay 2007). This has sometimes been the case in developing countries, when the introduction of VAT has resulted in substantial protests (see, for example, Osei 2000). Thus, the introduction of VAT - and occasionally changes in rates - certainly can make indirect taxes comparatively visible (Prichard 2010). However, an important part of pre-election declines in tax collection is expected to result not from permanent policy changes but from short- term changes in the effectiveness of enforcement, and these changes are likely to be relatively invisible to taxpayers. 
political budget cycles may be more pronounced where the 'quality' of elections is low, as this is expected to reflect institutional weakness. Consistent with this view, Erhart (2013) reports evidence that the negative impact of elections on taxation is larger where the quality of democracy is lower (as measured by the Polity IV dataset developed by Marshall et al. $(2012))^{4}$

Alongside these possibilities, the broader literature on tax compliance suggests a further, unexplored, possibility: tax collection may decline more rapidly prior to elections in which the incumbent is relatively unpopular, owing to popular resistance to taxation. Here the intuition is not that the government chooses to reduce taxation in order to court public support, but that more unpopular governments are unable to sustain tax revenue owing to increasingly aggressive tax evasion, tax avoidance and overt opposition to taxation. To illustrate, Prichard (2010) captures episodes from both Ghana and Kenya in the late 1990s in which the growing unpopularity of incumbent governments contributed to their inability to collect tax revenue prior to elections. In both cases the incumbent governments lost subsequent elections, while the newly-elected governments saw tax revenue increase substantially following elections as public support for taxation returned.

\section{Hypotheses}

The literature thus proposes a wide range of alternative hypotheses about the connections between elections and tax collection in developing countries, each of which carries with it broader assumptions and insights about the nature of the political incentives generated by elections. What follows seeks to test an encompassing set of possibilities, as follows.

\section{H1: Tax collection will be lower in election years, irrespective of the particular characteristics of individual elections.}

This is the most basic theory of political budget cycles, and is based on the implicit assumption that all elections will generate incentives for short-term policy adjustments largely irrespective of the existence of an organised opposition, the strength of electoral institutions, the age of a democracy or the extent of electoral competition. Erhart (2013) finds positive support for this contention in relation to taxation, as she pools all elections in her analysis and finds a negative and significant impact on tax collection.

\section{H2: The impact of elections on tax collection will be larger for contested multiparty elections.}

This hypothesis draws on the expectation that elections will only shape the political incentives of incumbent governments if there is a legal opposition against which the government must compete. Block et al. (2003) report evidence that multiparty elections do, in fact, produce larger political budget cycles in Africa, though they do not test whether this applies to taxation in particular. Brender and Drazen (2005: 1274) simply assume this relationship, and therefore exclude single party elections from their analysis, writing that, 'In our view, if the political budget cycle reflects the manipulation of fiscal policy to improve an incumbent's re-election chances, then it only makes sense in countries in which elections are competitive'. 
H3: The impact of elections on tax collection will be more limited where the 'quality' of elections and democracy is high and/or where elections are more free and fair.

This possibility reflects a belief that high quality or free and fair elections are indicative of more effective oversight by voters, stronger political institutions and correspondingly more limited scope for short-term policy manipulation. By contrast, low quality elections are likely to reflect weak oversight and institutions, and thus greater scope for incumbent governments to pursue short-term policy manipulation in search of electoral support. Erhart (2013) reports evidence that elections held in countries with weaker institutions of democracy, as measured by the Polity IV dataset, do, in fact, lead to larger political budget cycles. However, measuring the quality of democracy or elections is comparatively complex and open to alternative strategies, as discussed below.

\section{H4: The impact of elections on tax collection will be larger during 'founding' elections.}

This possibility reflects a similar logic to a focus on low quality elections: in countries transitioning to democracy voters may have less information and may be more heavily influenced by short-term policy manipulation, while institutional checks and balances on the incumbent government are expected to be more limited. Consistent with this view, Brender and Drazen (2005) report evidence of larger political budget cycles in new democracies, though limited to a sample of primarily higher-income countries, and limited to the expenditure side of the budget. Block et al. (2003) find no distinct impact of first elections on the existence and scope of political budget cycles.

H5: The impact of elections on tax collection will be larger where elections are more competitive, as reflected in the share of electoral support secured by the opposition.

It is a foundational feature of democratic theory that the impact of elections on political incentives will be greater where elections are more competitive. However, studies in developing countries have defined competitiveness extremely broadly, focusing on whether elections are contested by multiple parties (Block et al. 2003), but paying no attention to the margin of electoral victory - that is, to the extent to which the leading party faces a genuine electoral threat to its hold on power. By contrast, this study follows recent studies from Europe (Efthyvoulou 2012; Aidt et al. 2011) in asking whether political budget cycles are larger when the incumbent government faces a more substantive challenge to its hold on power, as measured by the opposition securing at least 40 per cent of seats in government, as discussed in greater detail below.

H6: Tax collection will decline more rapidly prior to elections in which the incumbent is removed from power.

Whereas the preceding hypotheses assume that governments choose to reduce tax collection prior to elections in order to court electoral support, this hypothesis explores the possibility that tax collection may instead decline as a result of popular resistance and expanded tax evasion and avoidance where the incumbent is particularly unpopular. While we are unable to measure the popularity of incumbent governments directly, a useful alternative is to focus attention on elections in which the incumbent is removed from office, based on the assumption that this removal from office is indicative of a lack of popularity.

H7: Elections (whether all elections or a subset of elections) will disproportionately affect indirect taxes rather than direct taxes

This hypothesis draws on Erhart (2013), who argues that governments will focus on preelection reductions in indirect taxes because they have a broader incidence than direct taxes, and are therefore expected to attract a larger number of voters. However, as noted above, 
the prevalence of patronage politics in developing countries, coupled with the relative invisibility of indirect taxes, may argue against such a focus on indirect taxes.

\section{Data and variables}

In order to test these hypotheses, a key innovation of this paper lies in employing vastly improved government revenue data, thus addressing concerns that earlier results may be driven by highly incomplete and occasionally inaccurate data for developing countries (Prichard et al. 2014). The paper draws on the newly-created ICTD GRD, which provides improved data coverage and accuracy across developing countries. These improvements are described in detail in Prichard et al. (2014), but can be summarised in two key elements.

First, the dataset achieves improved data coverage by combining mutually compatible data from multiple international sources. Whereas the IMF Government Finance Statistics (GFS) suffers from extensive missing data, these gaps can frequently be filled using regional sources or by drawing on country-level IMF Article IV reports. While potentially problematic from a strictly methodological perspective, in practice the low quality of the IMF GFS has led even IMF researchers themselves to abandon the GFS in favour of combining data from multiple international and country-level sources (e.g. Benedek et al 2012; Keen and Mansour 2009). What distinguishes the ICTD GRD is that this process has been more extensive and more careful than previous efforts, thus resulting in much more complete and accurate data. The end result is that whereas Erhart (2013) is able to include only fifty-six developing countries and a maximum of 1,238 country-year observations in her analysis, the new dataset allows the analysis here to include 1,870 observations across ninety-eight countries in the core results. ${ }^{5}$

Second, the ICTD GRD improves data accuracy by consistently distinguishing between taxes on natural resources and non-resource taxes on domestic businesses and citizens. This makes it possible to examine the impact of elections exclusively on non-resource tax collection. This is, in turn, a critical analytical distinction: we expect elections to affect levels of tax collection from citizens; there is no clear reason to expect elections to be related to changes in the corporate taxation of resource firms. ${ }^{6}$ By contrast, this distinction is generally not drawn in existing international sources, which frequently combine resource and nonresource tax revenue in a single measure of tax collection, with the risk of 'contaminating' the dependent variable of interest.

Drawing on this data we are thus able to construct our three dependent variables of interest: total tax revenue collection as a share of GDP (tottax), total direct tax collection as a share of GDP (direct), and total indirect tax collection as a share of GDP (indirect). Following standard international classifications, direct taxes include taxes on corporations, income taxes on individuals, property taxes and payroll taxes, but exclude social contributions, which are both analytically distinct and reported inconsistently across countries. Indirect taxes include sales taxes (including VAT), excise taxes, trade taxes and other taxes. Each of these tax variables is exclusive of resource revenue.

This number excludes countries with a population less than 1 million and data for Zimbabwe, which is a major outlier owing to hyperinflation in the 2000s. Exclusion of the latter does not alter key results, but is analytically appropriate. Of course, a variety of accounts suggest that governments regularly provide reduced taxes to resource firms particularly in the mining sector - in exchange for informal political contributions. However, there is no clear reason why such concessions should accelerate prior to elections, as any exchange of tax concessions for political contributions can occur at any point in the electoral cycle, and is likely to be negotiated at the point of establishing specific terms for new mining ventures (see, for example, Ayee et al. 2011: 21). 
While the most notable improvements in data quality relate to the revenue variables, the paper is also able to draw on a growing number of electoral datasets in order to capture distinct types of elections more precisely, and thus explore whether political budget cycles are conditional on these characteristics. The primary source of electoral data is the National Elections Across Democracy and Autocracy (NELDA) dataset (Hyde and Marinov 2012), which provides key descriptive information on all elections worldwide, as well as systematically coding key information about the conduct of those elections. The primary limitation of the NELDA dataset is that it does not include information on election outcomes, thus preventing estimation of the intensity of electoral competition. It is thus supplemented with data on electoral outcomes from the Database of Political Institutions (DPI), which provides the most complete cross-country information on the share of electoral support received by the government and opposition in individual elections (Beck et al. 2001).

Drawing on these datasets, we construct variables capturing the distinct subsets of elections in which we are interested. To begin we construct a variable for all elections (election), which is a binary dummy variable coded 1 for years in which there is an election and 0 in years without an election. Following the literature the variable includes all executive elections, as coded by the NELDA dataset. ${ }^{7}$ We next construct a dummy variable for contested multiparty elections which include a legal opposition (election_opp). ${ }^{8}$ In order to explore the distinct effect of high quality or free and fair elections, we then construct a dummy variable that takes the value 0 if there is evidence of significant electoral irregularities, and 1 if the election was relatively free of concerns (election_free), again as coded in the NELDA dataset. ${ }^{9}$ Alternative definitions are explored in the robustness checks, while the core results are based on the NELDA dataset for the sake of consistency. In order to focus on the potentially unique effect of elections in new democracies, we follow Block et al. (2003) by constructing a dummy variable for first elections (election_first) that is equal to 1 for either the first-ever democratic election in a country or the first democratic election after a significant hiatus, again as coded in the NELDA dataset. ${ }^{10}$

While the preceding variables largely follow the existing literature, the final two electoral variables are comparatively novel. In order to test whether tax collection declines more rapidly when the incumbent government is particularly unpopular, we create a dummy variable that is equal to 1 if the election results in a transition in power to the opposition (election_transition), as coded by the NELDA dataset. ${ }^{11}$ Finally, in order to test the distinct impact of competitive elections on tax collection, it is necessary to adopt a specific definition of competitiveness. We thus define a dummy variable for competitive elections (election_comp) that is equal to 1 if the government wins 60 per cent or less of all the seats

$7 \quad$ Executive elections are defined as elections in which the position of the effective head of state is contested, where the effective head of state may be an elected president, the leader of the largest party or coalition in parliament, or someone else.

$8 \quad$ It is coded by excluding elections for which any of the variables nelda3, nelda4 or nelda 5 is coded 'no' (Hyde and Marinov 2012).

$9 \quad$ Specifically, it excludes elections that involved boycotts by the opposition (variable: nelda 14), harassment of the opposition (nelda15), the cancellation of results favouring either the incumbent or the opposition (nelda 34 and nelda 32), reports of fraud by election monitors (nelda47), or refusal to participate by electoral monitors owing to perceived electoral fraud (nelda49).

10 An alternative option is to include multiple elections following the initial transition to democracy under the broader banner of new democracies, with de Haan and Klomp (2013: 392) offering an overview of different approaches in the literature. However, given the relatively recent adoption of democracy in many developing countries, such an approach ends up including a large share of all elections thus making a narrow focus on first elections more analytically useful here.

11 That said, this may be an imperfect measure of the concept of interest: incumbents may be highly unpopular without losing elections when elections are not free and fair, while in well-established democracies regular democratic transitions occur without that being a reflection of outright hostility to the outgoing government. Unfortunately, no superior measure of popular hostility to incumbent governments is available. 
in government, as coded by the DPI. ${ }^{12}$ In the robustness checks we then explore robustness to alternative definitions.

There is, of course, substantial overlap between these different electoral measures. For example, higher quality elections are, all else being equal, intuitively also more likely to be competitive. Similarly, elections resulting in a victory by the opposition are more likely to have been competitive, and to have been high quality. These connections are illustrated in Table 1. However, the more important message from the Table is that despite significant overlap each of the measures is also substantially distinct from the others, allowing for meaningful tests of competing hypotheses.

Table 1 Correlations between alternative election measures

\begin{tabular}{|l|l|l|l|l|l|l|}
\hline & Election_e5 & $\begin{array}{l}\text { Election_ } \\
\text { e5_opp }\end{array}$ & $\begin{array}{l}\text { Election_ } \\
\text { e5_free }\end{array}$ & $\begin{array}{l}\text { Election_e5_ } \\
\text { first }\end{array}$ & $\begin{array}{l}\text { Election_e5_ } \\
\text { comp }\end{array}$ & $\begin{array}{l}\text { Election_e5_ } \\
\text { transition }\end{array}$ \\
\hline Election_e5 & 1.000 & & & & & \\
\hline Election_e5_opp & 0.9271 & 1.000 & & & & \\
\hline Election_e5_free & 0.7277 & 0.7850 & 1.000 & & & \\
\hline Election_e5_first & 0.2832 & 0.3054 & 0.2325 & 1.000 & & \\
\hline Election_e5_comp & 0.5887 & 0.6350 & 0.6313 & 0.2508 & 1.000 & \\
\hline Election_e5_transition & 0.6004 & 0.6477 & 0.6016 & 0.1392 & 0.5713 & 1.000 \\
\hline
\end{tabular}

Source: Author's calculations.

Alongside defining these subsets of elections, the literature has long recognised that the fiscal effect of an election may be felt in the year prior to the election rather than in the election year itself - and that this needs to be accounted for in the analysis (Erhart 2013; Brender and Drazen 2005). Electorally-motivated reductions in tax collection seem likely to begin from six to twelve months, or even more, prior to the election itself, meaning that when an election occurs early in the calendar year the fiscal effect of the election is more likely to be felt in the year prior. ${ }^{13}$ As importantly, for elections that occur early in the year focusing on the fiscal effect in the actual election year will primarily capture the post-election fiscal effect. As such, for elections that occur early in the calendar year the effective election year for detecting fiscal effects is the year prior to the actual election year, as follows:

$$
\begin{aligned}
\text { Election_e }_{i, t} & =\text { Actual_Election }_{i, t+1} & & \text { if election_mont } h_{i, t+1} \leq k \\
& =\text { Actual_Election }_{i, t} & & \text { otherwise }
\end{aligned}
$$

where election_ek is the effective election year for detecting the fiscal impact, actual_election is the actual election year and $k$ takes a value 1 through 12 and captures the cut-off point for re-coding the effective election year, with elections earlier than month $k$ expected to have a fiscal effect in the year prior to the election. Decisions about the appropriate value of $k$ reflect assumptions about the relevant lag between the fiscal effect of an election and the election itself. Meanwhile, changes in the pattern of results as the value of $k$ is adjusted will offer insights into the actual length of the average lag between the fiscal effect and the election itself. Existing studies generally adopt a value of $k$ ranging from three to six months into the year. The core results here take a middle ground by setting $k=5$, denoted as election_e5,

12 There are important debates in the literature about the most appropriate means to measure electoral competitiveness, and none are perfect (Hyde and Marinov 2012). To an important extent this reflects the fact that a large margin of electoral victory may reflect a lack of competition, or may reflect the success of an incumbent in satisfying public demands in the face of a potentially competitive challenge. It is equally possible that a large margin of electoral victory could disguise significant intra-party electoral competition (e.g. Giliomee and Simkins 1999). However, a focus on the margin of victory is both conceptually straightforward and captures the core logic of democratic theory, and for this reason is the approach also adopted elsewhere in the literature (Efthyvoulou 2012; Aidt et al. 2011).

13 While not discussed in the literature, the lead time is intuitively potentially longer for tax reductions than changes in public expenditure, as tax benefits are more difficult to target and are constrained by the timing of tax payments throughout the fiscal year, thus making it more difficult to concentrate benefits immediately prior to an election. 
thus looking for a fiscal effect in the year prior when elections occur in the first five months of the year. The impact of alternative coding decisions is explored in the robustness checks.

Finally, the results that follow include a standard set of control variables drawn from the literature that are expected to influence levels of tax collection. The log level of per capita income (Igdp) captures the expectation that the tax share of GDP will be higher where incomes are higher. The share of agriculture in the national economy (agric) reflects the greater difficulty of taxing agricultural production. The level of imports (imports) is expected to have a positive impact on tax collection, by virtue of taxes explicitly on trade, as well as greater ease in taxing more formal economic transactions. The level of inflation (inflation) is expected to have a negative impact on the value of tax collection, while tax collection is expected to be higher when the growth rate per captita is higher (growthpc). All these variables are taken from the World Development Indicators (WDI) database. In addition, the regressions include two control variables that have often been overlooked in recent studies: the existence of a civil war (civil_war), constructed using data from the UCDP/PRIO dataset, which is expected to reduce tax collection, and the level of non-tax revenue as a share of GDP (totnontax), drawn from the ICTD GRD, which has been shown to lead to reduced tax effort (Bornhorst et al. 2008). Finally, following recent studies, the robustness checks also introduce controls for the level of urbanisation (urban), the share of the population under the age of 14 (under14), and the share of the population over the age of 65 (over65), all of which are taken from the WDI.

\section{Empirical strategy}

Following the literature we employ a dynamic estimation model of the form:

$$
\operatorname{Tax}_{i, t}=\varphi \text { Tax }_{i, t-l}+\beta_{1} \text { Election_e } 5_{i, t}+X_{i, t-1}^{\prime} \delta+\alpha_{i}+\lambda_{t}+e_{i, t}
$$

where the dependent variable, Tax, represents total tax revenue (tottax), direct tax revenue (direct) or indirect tax revenue (indirect) as shares of GDP, Election_e5 is our key independent variable, $X$ represents the battery of control variables, $\bar{\alpha}$ are the country fixed effects, $\lambda$ are year fixed effects and $e$ is the error term. The lagged dependent variable is included in order to account for the persistence of tax collection over time and any potential mean reverting dynamics. The analysis also includes fixed effects in order to focus on withincountry variation in tax collection in response to elections.

However, the fixed effects estimator is biased when employed alongside a lagged dependent variable, as the lagged dependent variable is correlated with the error term (Nickell 1981). As explained by Brender and Drazen (2005), the extent of this bias declines in the length of the time series and is likely to be relatively modest but non-negligible, given that our data covers three decades. The widely-used Arellano-Bond Generalised Method of Moments (GMM) estimator is likely to be more accurate (Blundell and Bond 1998), and all results are thus reported employing both the fixed effects estimator and the Sys-GMM estimator, the latter of which employs both lagged first differences and lagged levels of the explanatory variables as instruments. The Sys-GMM results are computed using Windmeijer robust standard errors, while the relevant tables report tests for second order autocorrelation as well as the Hansen test for invalid instruments (Roodman 2006, 2009).

In orde to explore the conditional impact of different types of elections the basic model is subsequently extended. To begin, we wish to explore the impact of focusing only on contested elections (election_e5_opp), as compared to focusing on all executive elections (election_e5). In order to do so, the model is extended to include two election variables: the baseline elections variable (election_e5) and the variable representing the more limited 
subset of elections of interest (election_e5_opp), as follows:

$\operatorname{Tax}_{i, t}=\varphi \operatorname{Tax}_{i, t-1}+\beta_{1}$ Election_e5 $_{i, t}+\beta_{2}$ Election_e5_opp $_{i, t}+X_{i, t-1}^{\prime} \delta+\alpha_{i}+\lambda_{t}+e_{i, t}$

Because contested elections are a subset of all elections, the interpretation of the results is similar to an interaction model. The coefficient $\beta_{1}$ on the baseline elections term (election_e5) tells us the independent effect of elections that are not contested. The coefficient $\beta_{2}$ on the subset of elections of interest (election_e5_opp) tells us whether that subset of elections (contested elections) is statistically significantly different from the baseline group of elections (uncontested elections). Finally, the overall effect of the subset of elections of interest - in this case contested elections - can be calculated as the linear combination of coefficients $\beta_{1}$ and $\beta_{2}$, which is reported in all the Tables to follow. The value of this linear combination is essentially identical to the result if we run a simpler regression that includes only the subset of elections of interest, as follows:

$\operatorname{Tax}_{i, t}=\varphi \operatorname{Tax}_{i, t-l}+\beta_{1}$ Election_e5_opp $_{i, t}+X_{i, t-1}^{\prime} \delta+\alpha_{i}+\lambda_{t}+e_{i, t}$

The added value of also including the baseline elections term, as in [3], is that it allows us to test formally whether the subset of elections of interest is statistically significantly different from all other elections. Ultimately, we are looking for evidence both that a particular subset of elections is significantly different from all other elections, as captured by $\beta_{2}$, and that the total effect of that subset of elections, as measured by the linear combination $\beta_{1}+\beta_{2}$, is statistically significant.

Having thus compared contested elections to all other elections we then proceed to test the distinct impact of all the other subsets of elections of interest: election_e5_free, election_e5_first, election_e5_transition and election_e5_comp. However, rather than comparing each subset of elections to all other elections (election_e5), we now use as the baseline all other contested elections (elections_e5_opp). While the results are robust to using all elections as the baseline, focusing exclusively on contested elections seems to be a more interesting and meaningful comparison. ${ }^{14}$ This gives us the following specification, where Electiontype_e5 represents each of the subsets of elections noted above:

$\operatorname{Tax}_{i, t}=\varphi T_{a x} x_{i,-l}+\beta_{1} E_{\text {Election_e5_opp }}+\beta_{2, t}$ Electiontype_e5 $+X_{i, t-1}^{\prime} \delta+\alpha_{i}+\lambda_{t}+e_{i, t}$

This allows us to test whether free, first, transition or competitive elections have a distinct impact on pre-election levels of tax collection, as well as the magnitude of this effect.

\section{Results}

Tables 2 and 3 present the core results, employing the fixed effects and Sys-GMM estimators in turn. Moving from left to right, each of the Tables reports results focusing, in turn, on all elections (election_e5), contested elections (election_e5_opp), free and fair elections (election_e5_free), first elections (election_e5_first), elections resulting in a transition from the incumbent government (election_e5_transition) and competitive elections (election_e5_comp). 14 And, indeed, some studies entirely exclude unopposed elections from the sample from the outset (Brender and Drazen
2005). 
Table 2 Effect of different election types on tax revenue - fixed effects

\begin{tabular}{|c|c|c|c|c|c|c|}
\hline & $\begin{array}{l}\text { (1) } \\
\text { All } \\
\text { elections }\end{array}$ & $\begin{array}{l}\text { (2) } \\
\text { Opposed } \\
\text { elections }\end{array}$ & $\begin{array}{l}\text { (3) } \\
\text { Free and } \\
\text { fair } \\
\text { elections }\end{array}$ & $\begin{array}{l}\text { (4) } \\
\text { First } \\
\text { elections }\end{array}$ & $\begin{array}{l}\text { (5) } \\
\text { Transition } \\
\text { elections }\end{array}$ & $\begin{array}{l}\text { (6) } \\
\text { Competitive } \\
\text { elections }\end{array}$ \\
\hline L.TotTax & $\begin{array}{l}0.7534^{\star \star *} \\
(0.0185)\end{array}$ & $\begin{array}{l}0.7535^{\star \star *} \\
(0.0184)\end{array}$ & $\begin{array}{l}0.7526^{\star \star \star} \\
(0.0184)\end{array}$ & $\begin{array}{l}0.7532^{\star \star \star} \\
(0.0184)\end{array}$ & $\begin{array}{l}0.7532^{\star \star \star} \\
(0.0184)\end{array}$ & $\begin{array}{l}0.7533^{\star * *} \\
(0.0184)\end{array}$ \\
\hline election_e5 & $\begin{array}{l}-0.0009 \\
(0.0009)\end{array}$ & $\begin{array}{l}-0.0012 \\
(0.0021)\end{array}$ & & & & \\
\hline election_e5_opp & & $\begin{array}{l}0.0003 \\
(0.0022)\end{array}$ & $\begin{array}{l}-0.0027^{*} \\
(0.0016)\end{array}$ & $\begin{array}{l}-0.0008 \\
(0.0010)\end{array}$ & $\begin{array}{l}0.0000 \\
(0.0013)\end{array}$ & $\begin{array}{l}0.0006 \\
(0.0013)\end{array}$ \\
\hline election_e5_free & & & $\begin{array}{l}0.0029^{\star} \\
(0.0017)\end{array}$ & & & \\
\hline election_e5_first & & & & $\begin{array}{l}-0.0014 \\
(0.0030)\end{array}$ & & \\
\hline election_e5_transition & & & & & $\begin{array}{l}-0.0024 \\
(0.0017)\end{array}$ & \\
\hline election_e5_comp & & & & & & $\begin{array}{l}-0.0033^{\star \star} \\
(0.0016)\end{array}$ \\
\hline $\operatorname{lgdp}$ & $\begin{array}{l}-0.0000 \\
(0.0022)\end{array}$ & $\begin{array}{l}-0.0000 \\
(0.0022)\end{array}$ & $\begin{array}{l}-0.0000 \\
(0.0022)\end{array}$ & $\begin{array}{l}-0.0000 \\
(0.0022)\end{array}$ & $\begin{array}{l}-0.0000 \\
(0.0022)\end{array}$ & $\begin{array}{l}0.0000 \\
(0.0022)\end{array}$ \\
\hline Agric & $\begin{array}{l}-0.0002^{\star *} \\
(0.0001)\end{array}$ & $\begin{array}{l}-0.0002^{\star *} \\
(0.0001)\end{array}$ & $\begin{array}{l}-0.0002^{\star *} \\
(0.0001)\end{array}$ & $\begin{array}{l}-0.0002^{\star *} \\
(0.0001)\end{array}$ & $\begin{array}{l}-0.0002^{\star *} \\
(0.0001)\end{array}$ & $\begin{array}{l}-0.0002^{\star *} \\
(0.0001)\end{array}$ \\
\hline Imports & $\begin{array}{l}0.0002^{\star \star \star} \\
(0.0000)\end{array}$ & $\begin{array}{l}0.0002^{* \star *} \\
(0.0000)\end{array}$ & $\begin{array}{l}0.0002^{\star \star \star} \\
(0.0000)\end{array}$ & $\begin{array}{l}0.0002^{* \star *} \\
(0.0000)\end{array}$ & $\begin{array}{l}0.0002^{\star \star \star} \\
(0.0000)\end{array}$ & $\begin{array}{l}0.0002^{\star \star \star} \\
(0.0000)\end{array}$ \\
\hline Civil_War & $\begin{array}{l}-0.0002 \\
(0.0014)\end{array}$ & $\begin{array}{l}-0.0002 \\
(0.0014)\end{array}$ & $\begin{array}{l}-0.0002 \\
(0.0014)\end{array}$ & $\begin{array}{l}-0.0002 \\
(0.0014)\end{array}$ & $\begin{array}{l}-0.0001 \\
(0.0014)\end{array}$ & $\begin{array}{l}-0.0001 \\
(0.0014)\end{array}$ \\
\hline TotNonTax & $\begin{array}{l}-0.0266^{\star \star} \\
(0.0112)\end{array}$ & $\begin{array}{l}-0.0266^{\star *} \\
(0.0112)\end{array}$ & $\begin{array}{l}-0.0266^{\star \star} \\
(0.0112)\end{array}$ & $\begin{array}{l}-0.0268^{\star \star} \\
(0.0112)\end{array}$ & $\begin{array}{l}-0.0270 * * \\
(0.0112)\end{array}$ & $\begin{array}{l}-0.0266^{\star \star} \\
(0.0113)\end{array}$ \\
\hline Inflation & $\begin{array}{l}0.0000 * * \\
(0.0000)\end{array}$ & $\begin{array}{l}0.0000 * * \\
(0.0000)\end{array}$ & $\begin{array}{l}0.0000 * * \\
(0.0000)\end{array}$ & $\begin{array}{l}0.0000 * * \\
(0.0000)\end{array}$ & $\begin{array}{l}0.0000 * * \\
(0.0000)\end{array}$ & $\begin{array}{l}0.0000 * * \\
(0.0000)\end{array}$ \\
\hline Growthpc & $\begin{array}{l}0.0002^{\star} \\
(0.0001)\end{array}$ & $\begin{array}{l}0.0002^{*} \\
(0.0001)\end{array}$ & $\begin{array}{l}0.0002^{*} \\
(0.0001)\end{array}$ & $\begin{array}{l}0.0002^{*} \\
(0.0001)\end{array}$ & $\begin{array}{l}0.0002^{\star} \\
(0.0001)\end{array}$ & $\begin{array}{l}0.0002^{*} \\
(0.0001)\end{array}$ \\
\hline$\beta 1+\beta 2$ & & $\begin{array}{l}-.0009 \\
(.0010)\end{array}$ & $\begin{array}{l}.0001 \\
(.0010)\end{array}$ & $\begin{array}{l}(-.0021) \\
(.0029)\end{array}$ & $\begin{array}{l}-.0023^{*} \\
(.0012)\end{array}$ & $\begin{array}{l}-.0027^{\star *} \\
(.0012)\end{array}$ \\
\hline No. of obs. & 1870 & 1870 & 1870 & 1870 & 1870 & 1870 \\
\hline No. of countries & 98 & 98 & 98 & 98 & 98 & 98 \\
\hline $\mathrm{R}^{2}$ & 0.689 & 0.689 & 0.689 & 0.689 & 0.689 & 0.689 \\
\hline
\end{tabular}

Notes: Standard errors in parentheses: ${ }^{*} p<0.10,{ }^{*} p<0.05,{ }^{* * *} p<0.01$. All results include fixed effects with robust standard errors. The coefficients in row $\beta 1+\beta 2$ capture the total magnitude and significance of the impact of the subset of elections reflected in $\beta 2$. 
Table 3 Effect of different election types on tax revenue - Sys-GMM

\begin{tabular}{|c|c|c|c|c|c|c|}
\hline & $\begin{array}{l}\text { (1) } \\
\text { All } \\
\text { elections }\end{array}$ & $\begin{array}{l}\text { (2) } \\
\text { Opposed } \\
\text { elections }\end{array}$ & $\begin{array}{l}\text { (3) } \\
\text { Free and } \\
\text { fair } \\
\text { elections }\end{array}$ & $\begin{array}{l}\text { (4) } \\
\text { First } \\
\text { elections }\end{array}$ & $\begin{array}{l}\text { (5) } \\
\text { Transition } \\
\text { elections }\end{array}$ & $\begin{array}{l}\text { (6) } \\
\text { Competitive } \\
\text { elections }\end{array}$ \\
\hline L.TotTax & $\begin{array}{l}0.7556^{\star * *} \\
(0.0556)\end{array}$ & $\begin{array}{l}0.7513^{\text {*** }} \\
(0.0605)\end{array}$ & $\begin{array}{l}0.7686^{\star * *} \\
(0.0730)\end{array}$ & $\begin{array}{l}0.7567^{\star * *} \\
(0.0665)\end{array}$ & $\begin{array}{l}0.7534^{\star \star *} \\
(0.0645)\end{array}$ & $\begin{array}{l}0.7536^{\star * *} \\
(0.0562)\end{array}$ \\
\hline election_e5 & $\begin{array}{l}-0.0008 \\
(0.0011)\end{array}$ & $\begin{array}{l}-0.0000 \\
(0.0020)\end{array}$ & & & & \\
\hline election_e5_opp & & $\begin{array}{l}-0.0011 \\
(0.0023)\end{array}$ & $\begin{array}{l}-0.0033^{\star \star} \\
(0.0015)\end{array}$ & $\begin{array}{l}-0.0010 \\
(0.0011)\end{array}$ & $\begin{array}{l}-0.0005 \\
(0.0013)\end{array}$ & $\begin{array}{l}0.0010 \\
(0.0014)\end{array}$ \\
\hline election_e5_free & & & $\begin{array}{l}0.0032^{*} \\
(0.0019)\end{array}$ & & & \\
\hline election_e5_first & & & & $\begin{array}{l}-0.0018 \\
(0.0033)\end{array}$ & & \\
\hline election_e5_transition & & & & & $\begin{array}{l}-0.0016 \\
(0.0021)\end{array}$ & \\
\hline election_e5_comp & & & & & & $\begin{array}{l}-0.0049 * * \\
(0.0020)\end{array}$ \\
\hline Igdp & $\begin{array}{l}0.0025 \\
(0.0018)\end{array}$ & $\begin{array}{l}0.0024 \\
(0.0019)\end{array}$ & $\begin{array}{l}0.0022 \\
(0.0015)\end{array}$ & $\begin{array}{l}0.0022 \\
(0.0017)\end{array}$ & $\begin{array}{l}0.0023 \\
(0.0016)\end{array}$ & $\begin{array}{l}0.0023 \\
(0.0015)\end{array}$ \\
\hline Agric & $\begin{array}{l}-0.0002^{*} \\
(0.0001)\end{array}$ & $\begin{array}{l}-0.0002^{\star *} \\
(0.0001)\end{array}$ & $\begin{array}{l}-0.0002^{\star *} \\
(0.0001)\end{array}$ & $\begin{array}{l}-0.0002^{\star \star} \\
(0.0001)\end{array}$ & $\begin{array}{l}-0.0002^{\star \star \star} \\
(0.0001)\end{array}$ & $\begin{array}{l}-0.0002^{\star \star} \\
(0.0001)\end{array}$ \\
\hline Imports & $\begin{array}{l}0.0003^{\star *} \\
(0.0001)\end{array}$ & $\begin{array}{l}0.0003^{\star \star} \\
(0.0001)\end{array}$ & $\begin{array}{l}0.0003^{\star *} \\
(0.0001)\end{array}$ & $\begin{array}{l}0.0003^{\star \star \star} \\
(0.0001)\end{array}$ & $\begin{array}{l}0.0003^{\star \star \star} \\
(0.0001)\end{array}$ & $\begin{array}{l}0.0003^{\star \star \star} \\
(0.0001)\end{array}$ \\
\hline Civil_War & $\begin{array}{l}-0.0010 \\
(0.0016)\end{array}$ & $\begin{array}{l}-0.0016 \\
(0.0019)\end{array}$ & $\begin{array}{l}-0.0013 \\
(0.0017)\end{array}$ & $\begin{array}{l}-0.0013 \\
(0.0017)\end{array}$ & $\begin{array}{l}-0.0017 \\
(0.0019)\end{array}$ & $\begin{array}{l}-0.0016 \\
(0.0018)\end{array}$ \\
\hline TotNonTax & $\begin{array}{l}-0.0649 * * * \\
(0.0164)\end{array}$ & $\begin{array}{l}-0.0682^{\star \star *} \\
(0.0163)\end{array}$ & $\begin{array}{l}-0.0649 * * * \\
(0.0174)\end{array}$ & $\begin{array}{l}-0.0660^{\star * \star} \\
(0.0147)\end{array}$ & $\begin{array}{l}-0.0691^{\star * \star} \\
(0.0145)\end{array}$ & $\begin{array}{l}-0.0675^{\star \star \star} \\
(0.0148)\end{array}$ \\
\hline Inflation & $\begin{array}{l}0.0000 * * \\
(0.0000)\end{array}$ & $\begin{array}{l}0.0000 \\
(0.0000)\end{array}$ & $\begin{array}{l}0.0000 * \star \\
(0.0000)\end{array}$ & $\begin{array}{l}0.0000 \\
(0.0000)\end{array}$ & $\begin{array}{l}0.0000 * \star \\
(0.0000)\end{array}$ & $\begin{array}{l}0.0000^{\star \star *} \\
(0.0000)\end{array}$ \\
\hline Growthpc & $\begin{array}{l}0.0002^{*} \\
(0.0001)\end{array}$ & $\begin{array}{l}0.0002^{\star} \\
(0.0001)\end{array}$ & $\begin{array}{l}0.0001 \\
(0.0001)\end{array}$ & $\begin{array}{l}0.0002 \\
(0.0001)\end{array}$ & $\begin{array}{l}0.0002^{\star \star} \\
(0.0001)\end{array}$ & $\begin{array}{l}0.0002^{\star} \\
(0.0001)\end{array}$ \\
\hline$\beta 1+\beta 2$ & & $\begin{array}{l}-.0012 \\
(.0012)\end{array}$ & $\begin{array}{l}-.0001 \\
(.0014)\end{array}$ & $\begin{array}{l}-.0028 \\
(.0033)\end{array}$ & $\begin{array}{l}-.0021 \\
(.0016)\end{array}$ & $\begin{array}{l}-.0039^{\star *} \\
(.0015)\end{array}$ \\
\hline $\mathrm{AR}(1)$ & 0.000 & 0.000 & 0.000 & 0.000 & 0.000 & 0.000 \\
\hline $\mathrm{AR}(2)$ & 0.338 & 0.332 & 0.318 & 0.341 & 0.320 & 0.339 \\
\hline Hansen & 0.390 & 0.979 & 0.993 & 0.991 & 0.996 & 0.998 \\
\hline No. of obs. & 1870 & 1870 & 1870 & 1870 & 1870 & 1870 \\
\hline No. of countries & 98 & 98 & 98 & 98 & 98 & 98 \\
\hline
\end{tabular}

Notes: Standard errors in parentheses: ${ }^{*} p<0.10,{ }^{* *} p<0.05,{ }^{* \star *} p<0.01$. All results are based on the two-step System-GMM procedure with Windmeijer standard errors. The $p$-values reported for the Hansen statistic are for the null hypothesis that instruments are valid. The values reported for $A R(2)$ are $p$-values for tests of second order autocorrelation. The coefficients in row $\beta 1+\beta 2$ capture the total magnitude and significance of the impact of the subset of elections reflected in $\beta 2$.

Across both estimation methods we fail to find a statistically significant negative effect of all elections on tax collection, with results reported in column 1 . While the coefficients on the elections variable are always negative, they fall far short of statistical significance at conventional levels, while the magnitude of the coefficient is in any case small, amounting to only a 0.1 per cent of GDP decline in tax collection. This stands in contrast to Erhart (2013), who reports a negative and significant relationship with a magnitude of 0.2 per cent of GDP.

The results in column 2 indicate that elections that are contested by an active opposition are no more likely than uncontested elections to result in a decline in tax collection. The overall impact of contested elections, in row $\beta_{1+} \beta_{2}$, is virtually identical to the coefficient on all elections in Table 1, while the coefficient on election_e5_opp is insignificant and small in magnitude. These patterns are again essentially identical between the fixed effects and SysGMM estimates. 
Column 3 focuses on free and fair elections. Across both the fixed effects and Sys-GMM models, the results indicate that free and fair elections are less likely to lead to reduced tax collection, while 'unfree' elections - that is, elections that experience electoral malfeasance have a statistically significant negative impact on tax collection (indicated by the coefficient on election_e5_opp). The magnitude of this effect is relatively large, amounting to around 0.3 per cent of GDP in both sets of estimates. This is consistent with political budget cycles being more likely in weak institutional environments that are home to opportunistic incumbents. However, robustness checks reported below suggest that this result is quite sensitive to particular definitions of what constitutes a free or unfree election.

Column 4 focuses on whether political budget cycles are more substantial during first elections. Again the results here do not offer support for this contention: neither the coefficient on elections_e5_first, nor the overall impact of first elections in row $\beta_{1+} \beta_{2}$, is significant in either the fixed effects or Sys-GMM estimates, despite comparatively large coefficients.

Column 5 reports results when focusing exclusively on elections in which the incumbent government loses power and is replaced. The fixed effects estimates indicate that elections resulting in a transition have a statistically significant negative impact on tax collection (row $\beta_{1}+\beta_{2}$ ). However, this result does not appear to be robust: none of the coefficients are significant in the Sys-GMM results, while even in the fixed effects results the coefficient on election_e5_transition is insignificant, indicating that transition elections are not statistically significantly different from all other contested elections.

Column 6 reports results focusing on competitive elections, and there is strong and statistically significant support for the existence of a negative relationship between competitive elections and tax collection. In both the fixed effects and Sys-GMM results there is a statistically significant negative coefficient on election_e5_comp, signalling that competitive elections have a significantly more negative impact on tax collection than all other contested elections. Meanwhile, the overall impact of competitive elections (row $\beta_{1}+\beta_{2}$ ) is in both cases negative and significant. The magnitude of the effect is substantial, with competitive elections estimated to lead to a 0.27 per cent of GDP decline in tax collection in the fixed effects estimates, and to a 0.39 per cent of GDP decline in the preferred Sys-GMM estimates. This result proves very robust to various checks reported below.

Having considered the impact of various types of elections on total tax revenue, Table 4 follows Erhart (2013) in presenting results in which the dependent tax variable is divided into its direct tax and indirect tax components. Results are again reported using both fixed effects and the Sys-GMM estimator. 
Table 4 Effect of elections on direct and indirect tax revenue

\begin{tabular}{|c|c|c|c|c|c|c|c|c|}
\hline & $\begin{array}{l}\text { (1) } \\
\text { Direct: } \\
\text { all } \\
\text { election } \\
\text { s } \\
\text { FE }\end{array}$ & $\begin{array}{l}\text { (2) } \\
\text { Direct: } \\
\text { all } \\
\text { election } \\
\text { s } \\
\text { Sys- } \\
\text { GMM }\end{array}$ & $\begin{array}{l}\text { (3) } \\
\text { Indirect: } \\
\text { all } \\
\text { election } \\
\text { s } \\
\text { FE }\end{array}$ & $\begin{array}{l}\text { (4) } \\
\text { Indirect: } \\
\text { all } \\
\text { election } \\
\text { s } \\
\text { Sys- } \\
\text { GMM }\end{array}$ & $\begin{array}{l}\text { (5) } \\
\text { Direct: } \\
\text { competitiv } \\
\text { e elections } \\
\text { FE }\end{array}$ & $\begin{array}{l}\text { (6) } \\
\text { Direct: } \\
\text { competitiv } \\
\text { e elections } \\
\text { Sys-GMM }\end{array}$ & $\begin{array}{l}\text { (7) } \\
\text { Indirect: } \\
\text { competitiv } \\
\text { e elections } \\
\text { FE }\end{array}$ & $\begin{array}{l}\text { (8) } \\
\text { Indirect: } \\
\text { competitiv } \\
\text { e elections } \\
\text { Sys-GMM }\end{array}$ \\
\hline L.Direct & $\begin{array}{l}0.7925^{\star \star \star} \\
(0.0337)\end{array}$ & $\begin{array}{l}0.8229 * \star * \\
(0.0642)\end{array}$ & & & $\begin{array}{l}0.7919 * * * \\
(0.0340)\end{array}$ & $\begin{array}{l}0.8652^{\star \star *} \\
(0.0506)\end{array}$ & & \\
\hline L.Indirect & & & $\begin{array}{l}0.6843^{\star \star *} \\
(0.0293)\end{array}$ & $\begin{array}{l}0.6945^{\star \star *} \\
(0.0681)\end{array}$ & & & $\begin{array}{l}0.6843^{\star * *} \\
(0.0292)\end{array}$ & $\begin{array}{l}0.7309^{\star * *} \\
(0.0621)\end{array}$ \\
\hline election_e5 & $\begin{array}{l}-0.0003 \\
(0.0005)\end{array}$ & $\begin{array}{l}-0.0007 \\
(0.0005)\end{array}$ & $\begin{array}{l}-0.0008 \\
(0.0007)\end{array}$ & $\begin{array}{l}-0.0006 \\
(0.0009)\end{array}$ & & & & \\
\hline $\begin{array}{l}\text { election_e5 } \\
\text { _comp }\end{array}$ & & & & & $\begin{array}{l}-0.0013^{*} \\
(0.0007)\end{array}$ & $\begin{array}{l}-0.0012^{*} \\
(0.0006)\end{array}$ & $\begin{array}{l}-0.0013^{*} \\
(0.0007)\end{array}$ & $\begin{array}{l}-0.0019^{\star *} \\
(0.0008)\end{array}$ \\
\hline Igdp & $\begin{array}{l}0.0006 \\
(0.0011)\end{array}$ & $\begin{array}{l}0.0009 \\
(0.0006)\end{array}$ & $\begin{array}{l}-0.0027 \\
(0.0034)\end{array}$ & $\begin{array}{l}0.0011 \\
(0.0021)\end{array}$ & $\begin{array}{l}0.0006 \\
(0.0011)\end{array}$ & $\begin{array}{l}0.0008 \\
(0.0005)\end{array}$ & $\begin{array}{l}-0.0027 \\
(0.0034)\end{array}$ & $\begin{array}{l}0.0007 \\
(0.0018)\end{array}$ \\
\hline Agric & $\begin{array}{l}-0.0000 \\
(0.0000)\end{array}$ & $\begin{array}{l}-0.0000 \\
(0.0000)\end{array}$ & $\begin{array}{l}-0.0001 \\
(0.0001)\end{array}$ & $\begin{array}{l}-0.0002^{*} \\
(0.0001)\end{array}$ & $\begin{array}{l}-0.0000 \\
(0.0000)\end{array}$ & $\begin{array}{l}-0.0000 \\
(0.0000)\end{array}$ & $\begin{array}{l}-0.0001 \\
(0.0001)\end{array}$ & $\begin{array}{l}-0.0002^{*} \\
(0.0001)\end{array}$ \\
\hline Imports & $\begin{array}{l}0.0001^{* * *} \\
(0.0000)\end{array}$ & $\begin{array}{l}0.0001^{* *} \\
(0.0000)\end{array}$ & $\begin{array}{l}0.0001^{* *} \\
(0.0000)\end{array}$ & $\begin{array}{l}0.0003^{*} \\
(0.0002)\end{array}$ & $\begin{array}{l}0.0001^{\star \star \star} \\
(0.0000)\end{array}$ & $\begin{array}{l}0.0000 \\
(0.0000)\end{array}$ & $\begin{array}{l}0.0001^{* *} \\
(0.0000)\end{array}$ & $\begin{array}{l}0.0003^{*} \\
(0.0001)\end{array}$ \\
\hline Civil_War & $\begin{array}{l}0.0007 \\
(0.0007)\end{array}$ & $\begin{array}{l}-0.0001 \\
(0.0007)\end{array}$ & $\begin{array}{l}-0.0007 \\
(0.0017)\end{array}$ & $\begin{array}{l}-0.0004 \\
(0.0017)\end{array}$ & $\begin{array}{l}0.0007 \\
(0.0007)\end{array}$ & $\begin{array}{l}-0.0001 \\
(0.0006)\end{array}$ & $\begin{array}{l}-0.0007 \\
(0.0017)\end{array}$ & $\begin{array}{l}0.0008 \\
(0.0013)\end{array}$ \\
\hline TotNonTax & $\begin{array}{l}-0.0146^{* *} \\
(0.0065)\end{array}$ & $\begin{array}{l}- \\
0.0135^{\star \star \star} \\
(0.0048)\end{array}$ & -0.0154 & $\begin{array}{l}- \\
0.0634^{\star \star \star} \\
(0.0159)\end{array}$ & $\begin{array}{l}-0.0147^{\star *} \\
(0.0065)\end{array}$ & $\begin{array}{l}-0.0112^{\star * *} \\
(0.0040)\end{array}$ & $\begin{array}{l}-0.0155 \\
(0.0165)\end{array}$ & $\begin{array}{l}-0.0585^{\star * *} \\
(0.0131)\end{array}$ \\
\hline Inflation & $\begin{array}{l}0.0000 \\
(0.0000)\end{array}$ & $\begin{array}{l}0.0000^{\star *} \\
(0.0000)\end{array}$ & $\begin{array}{l}0.0000 \\
(0.0000)\end{array}$ & $\begin{array}{l}-0.0000 \\
(0.0000)\end{array}$ & $\begin{array}{l}0.0000 \\
(0.0000)\end{array}$ & $\begin{array}{l}0.0000^{\star \star *} \\
(0.0000)\end{array}$ & $\begin{array}{l}0.0000 \\
(0.0000)\end{array}$ & $\begin{array}{l}0.0000 \\
(0.0000)\end{array}$ \\
\hline Growthpc & $\begin{array}{l}0.0001 \\
(0.0001)\end{array}$ & $\begin{array}{l}0.0001^{*} \\
(0.0001)\end{array}$ & $\begin{array}{l}0.0001 \\
(0.0001)\end{array}$ & $\begin{array}{l}0.0001 \\
(0.0001)\end{array}$ & $\begin{array}{l}0.0001 \\
(0.0001)\end{array}$ & $\begin{array}{l}0.0001^{*} \\
(0.0001)\end{array}$ & $\begin{array}{l}0.0001 \\
(0.0001)\end{array}$ & $\begin{array}{l}0.0001 \\
(0.0001)\end{array}$ \\
\hline $\mathrm{AR}(1)$ & & 0.000 & & 0.002 & & 0.000 & & 0.002 \\
\hline $\mathrm{AR}(2)$ & & 0.712 & & 0.276 & & 0.572 & & 0.272 \\
\hline Hansen & & 0.448 & & 0.271 & & 0.728 & & 0.810 \\
\hline No. of obs. & 1551 & 1551 & 1542 & 1542 & 1551 & 1551 & 1542 & 1542 \\
\hline $\begin{array}{l}\text { No. of } \\
\text { countries }\end{array}$ & 96 & 96 & 95 & 95 & 96 & 96 & 95 & 95 \\
\hline $\mathrm{R}^{2}$ & 0.692 & & 0.538 & & 0.692 & & 0.538 & \\
\hline
\end{tabular}

Notes: Standard errors in parentheses: ${ }^{*} p<0.10,{ }^{* *} p<0.05,{ }^{* * *} p<0.01$. Elections variable in columns $1-4$ is for all executive elections. Results in columns (1), (3), (5) and (7) employ fixed effects, while results in columns (2), (4), (6) and (8) are based on the two-step System-GMM procedure with Windmeijer standard errors. The p-values reported for the Hansen statistic are for the null hypothesis that instruments are valid. The values reported for $A R(2)$ are p-values for tests of second order autocorrelation.

Columns 1 through 4 mirror Erhart (2013) in reporting the impact of all elections on the two distinct components of tax revenue, and none of the results are statistically significant. This is unsurprising given that elections as a group similarly have no significant impact on total tax revenue. For a more meaningful test, Columns 5 through 8 explore whether competitive elections have a distinct impact on direct or indirect taxes. All the results are now significant, indicating that competitive elections have a significant and negative impact on both direct and indirect taxes, in relatively equal proportions. Contrary to Erhart (2013) there is no evidence that elections disproportionately affect indirect taxes. As discussed earlier, this is not necessarily surprising when the focus is on developing countries, as the role of patronage politics, coupled with the low visibility of indirect taxes, may frequently make reduced collection of direct taxes a useful electoral strategy despite their relatively narrow incidence.

Finally, in interpreting the results a brief note is needed about the diagnostic statistics. In order for Sys-GMM results to be valid we should fail to reject the null of no second order autocorrelation, and the null of the Hansen test of invalid instruments. All the results comfortably fail to reject in both cases, as reported in the Tables. However, Roodman (2009) 
warns that the Hansen test can be misleading in the presence of the excessive proliferation of instruments - something that is relatively likely with a long time series and multiple explanatory variables, as is the case here. Specifically, he warns that Hansen statistics that approach 1.000 can be evidence of the excessive proliferation of instruments, with corresponding results needing to be treated with caution. The Hansen statistics reported here frequently approach 1.000 , and this would normally imply that the results should be treated with caution. However, in practice, though not reported here, all the key findings are robust to adopting more parsimonious specifications. ${ }^{15}$ Critically, in these cases the Hansen test statistics drop substantially while leaving the core results in place, thus alleviating any concern about the results being driven by invalid instruments. In turn, the fact that the results are not driven by invalid instruments motivates the inclusion of more complete specifications here despite the large Hansen test statistics. ${ }^{16}$

\section{Robustness checks}

The most striking and novel finding is the positive relationship between competitive elections and tax collection. However, measuring electoral competitiveness is inherently challenging. One element of this challenge is that the choice of a cut-off point in deciding what constitutes competitiveness is somewhat arbitrary. Whereas the core results classify an election as competitive if the winning coalition controls less than 60 per cent of seats, Table 5 a reports results when the threshold for competitiveness is set to either 50 per cent (election_e5_comp50) or 70 per cent (election_e5_comp70) of seats.

\footnotetext{
15 Specifically, all results are also tested when employing only the subset of elections of interest as the explanatory

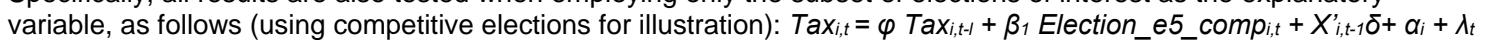
$+e_{i, t}$. In all cases competitive elections have a negative effect on tax collection, and all other results are also unchanged. All results are also tested using a simplified calibration of the Sys-GMM model, with elections treated as exogenous rather than being treated as endogenous, and the results are similarly robust to this change, with substantially lower Hansen test statistics. 
Table 5a Robustness checks: re-estimating results using alternative definitions of competitiveness

\begin{tabular}{|c|c|c|c|c|c|c|}
\hline & $\begin{array}{l}\text { (1) } \\
\text { Comp60 } \\
\text { FE }\end{array}$ & $\begin{array}{l}(2) \\
\text { Comp60 } \\
\text { Sys-GMM }\end{array}$ & $\begin{array}{l}\text { (3) } \\
\text { Comp50 } \\
\text { FE }\end{array}$ & $\begin{array}{l}\text { (4) } \\
\text { Comp50 } \\
\text { Sys-GMM }\end{array}$ & $\begin{array}{l}\text { (5) } \\
\text { Comp70 } \\
\text { FE }\end{array}$ & $\begin{array}{l}\text { (6) } \\
\text { Comp70 } \\
\text { Sys-GMM }\end{array}$ \\
\hline L.TotTax & $\begin{array}{l}0.7533^{\star * *} \\
(0.0184)\end{array}$ & $\begin{array}{l}0.7536^{\star \star *} \\
(0.0562)\end{array}$ & $\begin{array}{l}0.7526^{\star \star *} \\
(0.0184)\end{array}$ & $\begin{array}{l}0.7895^{\star \star *} \\
(0.0610)\end{array}$ & $\begin{array}{l}0.7533^{\star \star *} \\
(0.0184)\end{array}$ & $\begin{array}{l}0.7641^{\star * *} \\
(0.0512)\end{array}$ \\
\hline election_e5_opp & $\begin{array}{l}0.0006 \\
(0.0013)\end{array}$ & $\begin{array}{l}0.0010 \\
(0.0014)\end{array}$ & $\begin{array}{l}0.0002 \\
(0.0011)\end{array}$ & $\begin{array}{l}-0.0003 \\
(0.0013)\end{array}$ & $\begin{array}{l}0.0006 \\
(0.0018)\end{array}$ & $\begin{array}{l}-0.0001 \\
(0.0021)\end{array}$ \\
\hline election_e5_comp & $\begin{array}{l}-0.0033^{\star \star} \\
(0.0016)\end{array}$ & $\begin{array}{l}-0.0049^{\star *} \\
(0.0020)\end{array}$ & & & & \\
\hline election_e5_comp50 & & & $\begin{array}{l}-0.0042^{\star * *} \\
(0.0016)\end{array}$ & $\begin{array}{l}-0.0046^{* *} \\
(0.0018)\end{array}$ & & \\
\hline election_e5_comp70 & & & & & $\begin{array}{l}-0.0024 \\
(0.0020)\end{array}$ & $\begin{array}{l}-0.0024 \\
(0.0024)\end{array}$ \\
\hline$\beta 1+\beta 2$ & $\begin{array}{l}-.0027^{\star \star} \\
(.0012)\end{array}$ & $\begin{array}{l}-.0038^{\star \star} \\
(.0015)\end{array}$ & $\begin{array}{l}-.0041^{\star \star \star} \\
(.0014)\end{array}$ & $\begin{array}{l}-.0049 \star \star \star \\
(.0014)\end{array}$ & $\begin{array}{l}-.0018 \\
(0.0011)\end{array}$ & $\begin{array}{l}-.0025^{\star} \\
(.0013)\end{array}$ \\
\hline $\mathrm{AR}(1)$ & & 0.000 & & 0.000 & & 0.000 \\
\hline $\operatorname{AR}(2)$ & & 0.339 & & 0.312 & & 0.344 \\
\hline Hansen & & 0.998 & & 0.999 & & 0.970 \\
\hline No. of obs. & 1870 & 1870 & 1870 & 1870 & 1870 & 1870 \\
\hline No. of countries & 98 & 98 & 98 & 98 & 98 & 98 \\
\hline $\mathrm{R}^{2}$ & 0.689 & & 0.689 & & 0.689 & \\
\hline
\end{tabular}

Notes: Standard errors in parentheses: * $p<0.10,{ }^{* *} p<0.05,{ }^{* *} p<0.01$. Elections variable in columns $1-4$ is for all executive elections. Results in columns (1), (3), and (5) employ fixed effects, while results in columns (2), (4) and (6) are based on the two-step System-GMM procedure with Windmeijer standard errors. The p-values reported for the Hansen statistic are for the null hypothesis that instruments are valid. The values reported for AR(2) are p-values for tests of second order autocorrelation. The coefficients in row $\beta 1+\beta 2$ capture the total magnitude and significance of the impact of the subset of elections reflected in $\beta 2$. Estimates all include the standard set of controls - Igdp, agric, imports, civil_war, totnontax, inflation and growthpc - though not reported here to conserve space. Comp60 denotes that the government controls less than $60 \%$ of seats in government, Comp50 denotes less than $50 \%$, Comp 70 denotes less than $70 \%$.

The results are not only consistent with the argument so far, but add additional support. When the cut-off point for competitiveness is lowered to 50 per cent of seats, thus insisting on a still greater degree of competitiveness than the earlier results, we would expect an even larger effect. Consistent with this expectation, the magnitude of the effect of competitive elections (reported in columns 3 and 4) remains significant in both fixed effects and SysGMM estimates, while the magnitude of the effect increases by greater than 25 per cent - to almost 0.5 per cent of GDP (reported in row $\beta_{1}+\beta_{2}$ ). Meanwhile, when the threshold for competitiveness is increased - thus including a set of elections in which the opposition poses at best a marginal threat - we expect the coefficient on competitive elections to decline. Again, this is precisely what we find, as most of the relevant coefficients become insignificant. Only the overall effect of competitive elections remains negative and significant in the Sys-GMM estimates, but even there the magnitude of the coefficient is reduced by half relative to when the threshold for competitiveness is set at 50 per cent of seats.

Results reported in Table $5 b$ consider additional potential challenges in measuring competitiveness. One possibility is that incumbent governments may find it difficult in a vacuum to predict the competitiveness of upcoming elections, given the frequent absence of the types of polling data available in more developed states. In this context governments may rely on the competitiveness of previous elections to inform their expectations. To test this possibility, columns 3 and 4 report results when elections are coded as competitive when the government controls less than 60 per cent of seats in government prior to the election (election_e5_comp_past). Alternatively, reliance on the number of seats in government to measure competitiveness may be less accurate than relying on the overall share of the vote received by the government. Columns 5 and 6 correspondingly re-test the initial results when employing vote share rather than the share of seats in establishing whether an election is competitive (election_e5_comp_vote). In both cases the results are robust to these 
alternatives, with the significant coefficient on election_e5_comp_past seemingly attributable in part to the fact that governments use information on past elections to gauge the likely competitiveness of future elections, but also in large part to the fact that a country that experiences one competitive election is likely to experience others in the future. ${ }^{17}$

Table 5b Robustness checks: re-estimating key results with alternative measures of competitiveness

\begin{tabular}{|c|c|c|c|c|c|c|}
\hline & $\begin{array}{l}\text { (1) } \\
\text { Comp } \\
\text { FE }\end{array}$ & $\begin{array}{l}\text { (2) } \\
\text { Comp } \\
\text { Sys-GMM }\end{array}$ & $\begin{array}{l}\text { (3) } \\
\text { Comp_Past } \\
\text { Fe }\end{array}$ & $\begin{array}{l}\text { (4) } \\
\text { Comp_Past } \\
\text { Sys-GMM }\end{array}$ & $\begin{array}{l}\text { (5) } \\
\text { Comp_Vote } \\
\text { Fe }\end{array}$ & $\begin{array}{l}\text { (6) } \\
\text { Comp_Vote } \\
\text { Sys-GMM }\end{array}$ \\
\hline L.TotTax & $\begin{array}{l}0.7533^{\star * \star} \\
(0.0184)\end{array}$ & $\begin{array}{l}0.7536 \star \star \star \\
(0.0562)\end{array}$ & $\begin{array}{l}0.7533^{\star \star \star} \\
(0.0185)\end{array}$ & $\begin{array}{l}0.7525^{\star \star \star} \\
(0.0652)\end{array}$ & $\begin{array}{l}0.7530 * \star \star \\
(0.0183)\end{array}$ & $\begin{array}{l}0.8419 \star \star \star \star \\
(0.0464)\end{array}$ \\
\hline election_e5_opp & $\begin{array}{l}0.0006 \\
(0.0013)\end{array}$ & $\begin{array}{l}0.0010 \\
(0.0014)\end{array}$ & $\begin{array}{l}0.0007 \\
(0.0012)\end{array}$ & $\begin{array}{l}0.0007 \\
(0.0014)\end{array}$ & $\begin{array}{l}0.0001 \\
(0.0012)\end{array}$ & $\begin{array}{l}-0.0005 \\
(0.0015)\end{array}$ \\
\hline election_e5_comp & $\begin{array}{l}-0.0033^{\star \star} \\
(0.0016)\end{array}$ & $\begin{array}{l}-0.0049 * \star \\
(0.0020)\end{array}$ & & & & \\
\hline election_e5_comp_past & & & $\begin{array}{l}-0.0040 * * \\
(0.0016)\end{array}$ & $\begin{array}{l}-0.0054^{\star \star \star} \\
(0.0018)\end{array}$ & & \\
\hline election_e5_comp_vote & & & & & $\begin{array}{l}-0.0029 * \\
(0.0017)\end{array}$ & $\begin{array}{l}-0.0039 * \\
(0.0021)\end{array}$ \\
\hline$\beta 1+\beta 2$ & $\begin{array}{l}-.0027^{\star \star} \\
(.0011)\end{array}$ & $\begin{array}{l}-.0039 \star * \\
(.0015)\end{array}$ & $\begin{array}{l}-.0034^{\star \star} \\
(.0013)\end{array}$ & $\begin{array}{l}-.0047^{* \star \star} \\
(.0017)\end{array}$ & $\begin{array}{l}-.0028 \star \star \\
(.0013)\end{array}$ & $\begin{array}{l}-.0044^{\star \star} \\
(.0018)\end{array}$ \\
\hline $\operatorname{AR}(1)$ & & 0.000 & & 0.000 & & 0.000 \\
\hline $\operatorname{AR}(2)$ & & 0.339 & & 0.355 & & 0.359 \\
\hline Hansen & & 0.998 & & 0.999 & & 0.994 \\
\hline $\mathrm{N}$ & 1870 & 1870 & 1870 & 1870 & 1870 & 1870 \\
\hline N_g & 98 & 98 & 98 & 98 & 98 & 98 \\
\hline r2 & 0.689 & & 0.689 & & 0.689 & \\
\hline
\end{tabular}

Notes: Standard errors in parentheses: * $p<0.10,{ }^{* *} p<0.05,{ }^{* * *} p<0.01$. Elections variable in columns $1-4$ is for all executive elections. Results in columns (1), (3), and (5) employ fixed effects, while results in columns (2), (4) and (6) are based on the two-step System-GMM procedure with Windmeijer standard errors. The p-values reported for the Hansen statistic are for the null hypothesis that instruments are valid. The values reported for $A R(2)$ are $p$-values for tests of second order autocorrelation. The coefficients in row $\beta 1+\beta 2$ capture the total magnitude and significance of the impact of the subset of elections reflected in $\beta 2$. Estimates all include the standard set of controls - Igdp, agric, imports, civil war, totnontax, inflation and growthpc - though not reported here to conserve space. Comp_past denotes that the government controlled less than $60 \%$ of seats in government prior to the election, Comp_vote denotes the government winning less than $60 \%$ of total votes in legislative elections.

While the significant impact of competitive elections is the most important and consistent finding, the core results also provide support for the existence of political budget cycles in elections that are not free and fair, apparently reflecting the greater scope for pre-election fiscal manipulation where institutions are weak. However, defining free and fair is both complex and somewhat subjective, and Table 6 correspondingly reports results when employing alternative measures of free and fair. Results are reported employing Sys-GMM only, to conserve space, though all results are consistent when employing fixed effects.

17 The correlation coefficient between election_e5_comp and election_e5_comp_past is 0.7039 . 
Table 6 Robustness checks: re-estimating 'free and fair' results with alternative election datasets

\begin{tabular}{|c|c|c|c|c|c|c|}
\hline & $\begin{array}{l}\text { (1) } \\
\text { Free and } \\
\text { fair } \\
\text { Sys-GMM }\end{array}$ & $\begin{array}{l}(2) \\
\text { Free or fair } \\
\text { Sys-GMM }\end{array}$ & $\begin{array}{l}\text { (3) } \\
\text { Polity>70 } \\
\text { Sys-GMM }\end{array}$ & $\begin{array}{l}\text { (4) } \\
\text { No fraud } \\
\text { Sys-GMM }\end{array}$ & $\begin{array}{l}(5) \\
\text { 'Good' } \\
\text { elections } \\
\text { Sys-GMM }\end{array}$ & $\begin{array}{l}(6) \\
\text { 'Ambiguous' } \\
\text { elections } \\
\text { Sys-GMM }\end{array}$ \\
\hline L.TotTax & $\begin{array}{l}0.7839 * \star * \\
(0.0644)\end{array}$ & $\begin{array}{l}0.7291^{\star \star \star} \\
(0.0699)\end{array}$ & $\begin{array}{l}0.7863^{\star \star \star} \\
(0.0589)\end{array}$ & $\begin{array}{l}0.7594^{\star \star \star} \\
(0.0619)\end{array}$ & $\begin{array}{l}0.6973^{\star \star \star} \\
(0.0847)\end{array}$ & $\begin{array}{l}0.7016^{\star \star *} \\
(0.0795)\end{array}$ \\
\hline election_e5_opp & $\begin{array}{l}-0.0009 \\
(0.0015)\end{array}$ & $\begin{array}{l}-0.0034^{\star *} \\
(0.0014)\end{array}$ & $\begin{array}{l}-0.0012 \\
(0.0019)\end{array}$ & $\begin{array}{l}-0.0013 \\
(0.0022)\end{array}$ & $\begin{array}{l}-0.0010 \\
(0.0021)\end{array}$ & $\begin{array}{l}-0.0006 \\
(0.0029)\end{array}$ \\
\hline election_e5_ff & $\begin{array}{l}0.0006 \\
(0.0026)\end{array}$ & & & & & \\
\hline election_e5_fof & & $\begin{array}{l}0.0031 \\
(0.0020)\end{array}$ & & & & \\
\hline election_e5_polity70 & & & $\begin{array}{l}-0.0009 \\
(0.0022)\end{array}$ & & & \\
\hline election_e5_nofraud_dpi & & & & $\begin{array}{l}-0.0000 \\
(0.0026)\end{array}$ & & \\
\hline election_e5_qedgood & & & & & $\begin{array}{l}-0.0001 \\
(0.0022)\end{array}$ & \\
\hline election_e5_qedok & & & & & & $\begin{array}{l}-0.0006 \\
(0.0030)\end{array}$ \\
\hline$\beta 1+\beta 2$ & $\begin{array}{l}-.0003 \\
(.0022)\end{array}$ & $\begin{array}{l}-.0003 \\
(.0016)\end{array}$ & $\begin{array}{l}-.0021 \\
(.0013)\end{array}$ & $\begin{array}{l}-.0013 \\
(.0011)\end{array}$ & $\begin{array}{l}-.0010 \\
(.0015)\end{array}$ & $\begin{array}{l}-.0012 \\
(.0014)\end{array}$ \\
\hline $\operatorname{AR}(1)$ & 0.000 & 0.000 & 0.000 & 0.000 & 0.000 & 0.000 \\
\hline $\operatorname{AR}(2)$ & 0.331 & 0.322 & 0.344 & 0.333 & 0.916 & 0.885 \\
\hline Hansen & 0.982 & 0.974 & 0.976 & 0.995 & 0.917 & 0.666 \\
\hline No. of obs. & 1870 & 1870 & 1870 & 1870 & 1400 & 1400 \\
\hline No. of countries & 98 & 98 & 98 & 98 & 96 & 96 \\
\hline
\end{tabular}

Notes: Standard errors in parentheses: * $p<0.10,{ }^{* *} p<0.05,{ }^{* \star *} p<0.01$. All results are based on the two-step System-GMM procedure with Windmeijer standard errors. The $p$-values reported for the Hansen statistic are for the null hypothesis that instruments are valid. The values reported for $\mathrm{AR}(2)$ are $\mathrm{p}$-values for tests of second order autocorrelation. The coefficients in row $\beta 1+\beta 2$ capture the total magnitude and significance of the impact of the subset of elections reflected in $\beta 2$. Estimates all include the standard set of controls - Igdp, agric, imports, civil war, totnontax, inflation and growthpc - though not reported here to conserve space.

Columns 1 reports results where elections are coded free and fair based on the database of free and fair elections developed by Bishop and Hoeffler (2014), with the elections variable (election_e5_ff) coded 1 for elections that are classified as both free and fair. Column 2 employs a looser definition, with the elections variable (election_e5_fof) coded 1 if the election is coded either free or fair by Bishop and Hoeffler (2014). Most of the coefficients are insignificant. However, the results in column 2 indicate that elections that are neither free nor fair (captured by the coefficient on election_e5_opp) have a negative and statistically significant impact on pre-election tax collection, amounting to more than 0.3 per cent of GDP.

However, subsequent columns suggest that this finding is quite sensitive to coding choices, and should be treated with caution. Column 3 focuses on high quality elections by coding the elections variable (election_e5_polity70) 1 where the polity score in the country (drawn from the Polity IV database. at the time of the election is above a 4 (on a scale of -10 to 10). Column 4 reports results when the elections variable (election_e5_nofraud) is coded 1 for elections in which there was no electoral fraud sufficient to affect electoral results, as coded by the Database of Political Institutions (Beck et al. 2001). Column 5 captures results when the elections variable (election_e5_qedgood) is coded 1 for elections that are coded acceptable in the Quality of Elections Database (QED) developed by Kelley and Kolev (2010); while column 6 reports results employing a slightly looser definition, with the elections variable (election_e5_qedok) coded 1 for elections that are coded acceptable or ambiguous in the QED. The results in columns 3 through 6 are universally insignificant, with inconsistent signs, indicating that any relationship between the extent to which an election was free and 
fair and the extent of political budget cycles is extremely sensitive to coding decisions, and thus not terribly robust.

Beyond considering alternative electoral measures, all the findings are subjected to a series of overarching robustness tests. Though nor reported here in order to conserve space, all results are tested for alternative sets of control variables, including the addition of new controls for the share of the population under the age of fourteen, the share of the population over the age of sixty-five and the level of urbanisation, each of which appears elsewhere in the literature. The statistically significant results for competitive elections are completely unchanged by adding these new variables, in either fixed effects or Sys-GMM specifications.

All of the results are also replicated employing data exclusively at the central government level - whereas the core analysis employs the preferred ICTD dataset, which includes general government data where relevant for federal states (see description in Prichard et al. 2014). Conceptually, it is ambiguous whether it is more appropriate to employ central or general government data. The elections that are the explanatory variable in the analysis are at the central government level, which may argue for focusing only on central government tax collection. On the other hand, central government elections are often accompanied by subnational elections, while in any case the central government is likely to be able also to influence collection at the state/provincial or local government levels, and a failure to consider general government tax collection may obscure effects that occur at that level. In practice, the effect of competitive elections remains significant and of similar magnitude when relying exclusively on central government data, while all the other results also remain unchanged, thus further reinforcing confidence in the results (Table 7).

Table 7 Robustness checks: re-estimating results using only central government revenue data

\begin{tabular}{|c|c|c|c|c|c|c|}
\hline & $\begin{array}{l}\text { (1) } \\
\text { All } \\
\text { elections } \\
\text { Sys-GMM }\end{array}$ & $\begin{array}{l}\text { (2) } \\
\text { Contested } \\
\text { elections } \\
\text { Sys-GMM }\end{array}$ & $\begin{array}{l}\text { (3) } \\
\text { Free } \\
\text { elections } \\
\text { Sys-GMM }\end{array}$ & $\begin{array}{l}\text { (4) } \\
\text { First } \\
\text { elections } \\
\text { Sys-GMM }\end{array}$ & $\begin{array}{l}(6) \\
\text { Transitional } \\
\text { elections } \\
\text { Sys-GMM }\end{array}$ & $\begin{array}{l}\text { (5) } \\
\text { Competitive } \\
\text { elections } \\
\text { Sys-GMM }\end{array}$ \\
\hline L.tottax_cen & $\begin{array}{l}0.7060^{* * *} \\
(0.0576)\end{array}$ & $\begin{array}{l}0.6396^{* * *} \\
(0.0738)\end{array}$ & $\begin{array}{l}0.6513^{\star \star \star} \\
(0.0743)\end{array}$ & $\begin{array}{l}0.6597^{\star * *} \\
(0.0617)\end{array}$ & $\begin{array}{l}0.7168^{\star \star \star} \\
(0.0728)\end{array}$ & $\begin{array}{l}0.7240^{\star \star *} \\
(0.0790)\end{array}$ \\
\hline election_e5 & $\begin{array}{l}-0.0010 \\
(0.0010)\end{array}$ & $\begin{array}{l}-0.0024 \\
(0.0031)\end{array}$ & & & & \\
\hline election_e5_opp & & $\begin{array}{l}0.0013 \\
(0.0033)\end{array}$ & $\begin{array}{l}-0.0026^{\star} \\
(0.0014)\end{array}$ & $\begin{array}{l}-0.0012 \\
(0.0012)\end{array}$ & $\begin{array}{l}-0.0011 \\
(0.0013)\end{array}$ & $\begin{array}{l}0.0005 \\
(0.0015)\end{array}$ \\
\hline election_e5_free & & & $\begin{array}{l}0.0024 \\
(0.0019)\end{array}$ & & & \\
\hline election_e5_first & & & & $\begin{array}{l}-0.0020 \\
(0.0035)\end{array}$ & & \\
\hline election_e5_transition & & & & & $\begin{array}{l}-0.0010 \\
(0.0019)\end{array}$ & \\
\hline election_e5_comp & & & & & & $\begin{array}{l}-0.0035^{\star} \\
(0.0020)\end{array}$ \\
\hline$\beta 1+\beta 2$ & & $\begin{array}{l}-.0011 \\
(.0012)\end{array}$ & $\begin{array}{l}-.0002 \\
(.0014)\end{array}$ & $\begin{array}{l}-.0032 \\
(.0035)\end{array}$ & $\begin{array}{l}-.0021 \\
(.0018)\end{array}$ & $\begin{array}{l}-.0030^{\star \star} \\
(.0014)\end{array}$ \\
\hline $\mathrm{AR}(1)$ & 0.000 & 0.000 & 0.000 & 0.000 & 0.000 & 0.000 \\
\hline $\operatorname{AR}(2)$ & 0.411 & 0.420 & 0.416 & 0.396 & 0.402 & 0.401 \\
\hline Hansen & 0.435 & 0.990 & 0.999 & 0.983 & 0.998 & 0.999 \\
\hline No. of obs. & 1793 & 1793 & 1793 & 1793 & 1793 & 1793 \\
\hline No. of countries & 92 & 92 & 92 & 92 & 92 & 92 \\
\hline
\end{tabular}

Notes: Standard errors in parentheses: ${ }^{*} p<0.10,{ }^{* *} p<0.05,{ }^{* \star *} p<0.01$. All results are based on the two-step System-GMM procedure with Windmeijer standard errors. The $p$-values reported for the Hansen statistic are for the null hypothesis that instruments are valid. The values reported for AR(2) are $\mathrm{p}$-values for tests of second order autocorrelation. The coefficients in row $\beta 1+\beta 2$ capture the total magnitude and significance of the impact of the subset of elections reflected in $\beta 2$. Estimates all include the standard set of controls - Igdp, agric, imports, civil_war, totnontax, inflation and growthpc - though not reported here to conserve space. 
Results are similarly replicated using alternative samples of countries, with Tables A1 through A4 in the Appendix reporting core results for, in turn: all countries, all non-resource dependent countries, all non-resource dependent developing countries and low-income countries exclusively. The results are all broadly consistent with those reported so far. When developed countries are included in the sample (Tables A1 and A2), competitive elections continue to have a statistically significant negative impact on tax collection, and are statistically significantly different from all other elections. However, the magnitude of the effect declines somewhat, which is what we would expect given previous research findings that political budget cycles are less pronounced (or non-existent) in OECD countries (de Haan and Klomp 2013). When we focus exclusively on developing countries, but now exclude major natural resource producers (Table A3), the results are almost identical to those for all developing countries, removing any concern that fiscal dynamics in resource states may be shaping the results. The only non-conforming result comes when we focus exclusively on low and lower middle-income countries, as in this case the impact of competitive elections becomes insignificant. However, this result does not appear to be fundamentally at odds with the results so far: the coefficient is still negative, and the magnitude comparable to earlier results, with the loss of significance reflecting larger standard errors with a much reduced sample size.

The analysis is also replicated employing alternative definitions of the effective election year. As described above, in the core results we look for the fiscal effect of elections in the year prior to elections if the election occurs in the first five months of a given year. However, this cut-off point is somewhat arbitrary, reflecting a best guess about how long prior to an election the fiscal effect of that election is likely to be felt. Tables A5 through A8 in the Appendix correspondingly report results when either (a) we look for the fiscal effect of an election strictly in the year in which it occurred (election_e0), or (b) elections are recoded to the previous years if they occurred in the first three (election_e3), four (election_e4) or six (election_e6) months of the year, respectively.

If our results are robust then we should not necessarily find that they are unchanged across these alternatives. Instead, their significance should decline when employing election_e 0 . For elections that occur early in the year the results employing election_e 0 are capturing primarily post-election patterns of tax collection, rather than the pre-election effect on tax collection on which we are focused. As importantly, employing the election_e0 variable implies ignoring any fiscal effect of elections that occurs in the year prior to the election - a particularly problematic oversight for elections that occur early in the year. Meanwhile, expectations about the results using the election variables election_e3, election_e4 and election_e6 are more ambiguous, as they depend entirely on how far in advance of elections any fiscal effect takes place. As such, the pattern of significance is expected to provide insight into the time period over which elections tend to affect tax collection - with, for example, stronger results for election_e6 implying that the fiscal effect of elections occurs well in advance of the elections themselves.

Again the results adhere closely to expectation, reinforcing confidence in the findings. As expected, the impact of competitive elections - and of all other types of elections - drops sharply when we employ election_e0, reported in Table A5. Tellingly, the impact of transition elections (election_e0_transition) is now positive, consistent with the replacement of an unpopular incumbent resulting in large post-election improvements in tax collection. Turning to Tables A6 through A8 the results for competitive elections follow a consistent pattern: the impact of competitive elections is negative, but insignificant, when employing election_e3 (Table A8); negative, significant and large in magnitude when employing election_e4 (Table A7) and election_e5 (Table 3); remains negative and significant, but with a slightly lower magnitude, when employing election_e6 (Table A6); and is again insignificant when 
employing election_e7. ${ }^{18}$ This pattern is summarised in Table 8 . The fact that the results become stronger as the lag initially grows longer is consistent with the effect of elections on tax collection occurring well in advance of those elections. Meanwhile, the fact that the effect eventually begins to dissipate as the implied lag grows too long captures the fact that focusing on the year prior to elections eventually fails to capture effects that occur more immediately prior to elections.

Table 8 Robustness checks: effect of competitive elections using different definitions of 'effective' election year

\begin{tabular}{|c|c|c|c|c|c|c|}
\hline & $\begin{array}{l}\text { (1) } \\
\text { Comp E0 } \\
\text { Sys-GMM }\end{array}$ & $\begin{array}{l}\text { (2) } \\
\text { Comp E3 } \\
\text { Sys-GMM }\end{array}$ & $\begin{array}{l}\text { (3) } \\
\text { Comp E4 } \\
\text { Sys-GMM }\end{array}$ & $\begin{array}{l}\text { (4) } \\
\text { Comp E5 } \\
\text { Sys-GMM }\end{array}$ & $\begin{array}{l}\text { (5) } \\
\text { Comp E6 } \\
\text { Sys-GMM }\end{array}$ & $\begin{array}{l}\text { (6) } \\
\text { Comp E7 } \\
\text { Sys-GMM }\end{array}$ \\
\hline L.TotTax & $\begin{array}{l}0.7599 \star \star \star \\
(0.0608)\end{array}$ & $\begin{array}{l}0.7815^{\star \star \star} \\
(0.0611)\end{array}$ & $\begin{array}{l}0.7692^{\star * \star} \\
(0.0583)\end{array}$ & $\begin{array}{l}0.7536 * * \star \\
(0.0562)\end{array}$ & $\begin{array}{l}0.7928^{\star \star \star} \\
(0.0605)\end{array}$ & $\begin{array}{l}0.7664^{\star \star \star} \\
(0.0475)\end{array}$ \\
\hline election_ek_opp & $\begin{array}{l}0.0004 \\
(0.0018)\end{array}$ & $\begin{array}{l}-0.0006 \\
(0.0016)\end{array}$ & $\begin{array}{l}0.0010 \\
(0.0014)\end{array}$ & $\begin{array}{l}0.0010 \\
(0.0014)\end{array}$ & $\begin{array}{l}-0.0004 \\
(0.0017)\end{array}$ & $\begin{array}{l}-0.0015 \\
(0.0016)\end{array}$ \\
\hline election_e0_comp & $\begin{array}{l}-0.0008 \\
(0.0021)\end{array}$ & & & & & \\
\hline election_e3_comp & & $\begin{array}{l}-0.0012 \\
(0.0019)\end{array}$ & & & & \\
\hline election_e4_comp & & & $\begin{array}{l}-0.0051^{\star \star \star} \\
(0.0018)\end{array}$ & & & \\
\hline election_e5_comp & & & & $\begin{array}{l}-0.0049 * * \\
(0.0020)\end{array}$ & & \\
\hline election_e6_comp & & & & & $\begin{array}{l}-0.0031 \\
(0.0022)\end{array}$ & \\
\hline election_e7_comp & & & & & & $\begin{array}{l}-0.0002 \\
(0.0020)\end{array}$ \\
\hline$\beta 1+\beta 2$ & $\begin{array}{l}-.0004 \\
(.0011)\end{array}$ & $\begin{array}{l}-.0018 \\
(.0014)\end{array}$ & $\begin{array}{l}-.0041^{\star \star \star} \\
(.0013)\end{array}$ & $\begin{array}{l}-.0038 \star \star \\
(.0015)\end{array}$ & $\begin{array}{l}-.0035^{\star \star} \\
(0.0014)\end{array}$ & $\begin{array}{l}-.0017 \\
(0.0011)\end{array}$ \\
\hline $\mathrm{AR}(1)$ & 0.000 & 0.000 & 0.000 & 0.000 & 0.000 & 0.000 \\
\hline $\mathrm{AR}(2)$ & 0.360 & 0.349 & 0.327 & 0.339 & 0.326 & 0.342 \\
\hline Hansen & 0.953 & 0.954 & 0.999 & 0.998 & 0.988 & 0.999 \\
\hline No. of obs. & 1870 & 1870 & 1870 & 1870 & 1870 & 1870 \\
\hline No. of countries & 98 & 98 & 98 & 98 & 98 & 98 \\
\hline
\end{tabular}

Notes: Standard errors in parentheses: ${ }^{*} p<0.10,{ }^{* *} p<0.05,{ }^{* \star *} p<0.01$. All results are based on the two-step System-GMM procedure with Windmeijer standard errors. The $p$-values reported for the Hansen statistic are for the null hypothesis that instruments are valid. The values reported for AR(2) are p-values for tests of second order autocorrelation. The coefficients in row $\beta 1+\beta 2$ capture the total magnitude and significance of the impact of the subset of elections reflected in $\beta 2$. Estimates all include the standard set of controls - Igdp, agric, imports, civil_war, totnontax, inflation and growthpc - though not reported here to conserve space.

Finally, the results in Tables A1 through A8 serve to reinforce scepticism about the other hypotheses tested in the paper. Across all the alternative samples of countries and definitions of the election year, there is not a single specification in which all elections, contested elections or first elections have a statistically significant negative impact on tax collection - though the coefficient on first elections is always relatively large in magnitude. In the specification focusing exclusively on low-income countries there is evidence that unfree elections have a negative effect on tax collection, at the 10 per cent level of statistical significance. However, this result does not hold for other subsets of countries and, though not reported here, is similarly not robust to the adoption of more parsimonious specifications or the adoption of a fixed effects specification, implying the need for caution. In several specifications the overall effect of transition elections (row $\left.\beta_{1}+\beta_{2}\right)$ is similarly negative and significant. However, this result is again relatively fragile: in none of the specifications is the coefficient on election_ek_transition significant, while the result is highly variable in response to changes in the definition of the effective election year. Lastly, there is no clear pattern in the distribution of the effect of competitive elections between direct and indirect taxes. In two

18 Results available on request from the author. 
instances - for election_e4_comp and for non-resource developing countries - the effect on indirect taxes is negative and significant, while the effect on direct taxes is not. However, in the vast majority of specifications the effect on direct and indirect taxes is either both significant, or both insignificant, thus arguing against drawing any conclusions about distinct effects.

\section{Discussion}

The starting point for this paper was a concern that earlier studies of the impact of elections on tax collection were plagued by problematic data, which may have resulted in misleading results. As has been widely noted elsewhere, econometric research in the social sciences has frequently valued methodological innovation over careful attention to data quality (Herrera and Kapur 2007; Jerven 2013). Consistent with this starting point, the results here partially contradict recent results reported by Erhart (2013). First, there is no consistent and statistically significant evidence that elections in general have led to reduced tax collection in election years. This is true both when focusing on all elections, and when focusing more narrowly on contested multiparty elections. Second, there is no consistent evidence that elections have disproportionately affected indirect taxes. From the vantage point of theory, neither of these findings is necessarily surprising. There are clear reasons why tax collection may be less affected by political budget cycles than public spending, given lower visibility, higher costs and the fact that reduced collection may also imply reduced spending. Meanwhile, in many developing countries the nature of patronage-based politics, coupled with the relative invisibility of indirect taxes, can account for governments targeting both direct and indirect taxes in advance of elections.

The more important finding is of a substantial and robust impact of competitive elections on pre-election tax collection, amounting to anywhere from 0.3 per cent to 0.5 per cent of GDP depending on the specification. The consistency of this result across a range of robustness tests is, in turn, particularly compelling. The negative relationship becomes stronger as the definition of competitiveness becomes more restrictive, and weaker as the definition of competitiveness is relaxed, precisely in line with theoretical expectations. The pattern of results as we alter the definition of the effective election year is equally striking: the results grow stronger as the lag between fiscal effects and elections is increased to the levels predicted by theory, while the strength of the results subsequently declines as the lag becomes so long as to fail to capture the short-term fiscal effect of elections. The fact that the results vary systematically with changes in the definition of competitiveness and effective election year offers, somewhat counter-intuitively, much greater confidence in the robustness of the results than would be the case if the results were relatively invariant - or varied in unpredictable ways - across these changes.

Block et al. (2003) have previously reported evidence that political budget cycles have become larger where elections have been competitive, but they define competitiveness simply as the existence of multiparty competition. The results here suggest that competition defined so minimally has had little impact on government behaviour, at least in relation to taxation. It is only when the opposition has been sufficient electorally to have a meaningful possibility of electoral victory that incumbent governments have been driven to offer tax reductions in an effort to secure electoral support. This distinction is intuitively attractive: from a rationalist perspective there is little reason why the existence of only a very weak opposition would compel a government to inflict harm on itself by willingly undermining its revenue base. It is only when its survival is in danger that a government is intuitively likely to take such a step, and this intuition is confirmed by the results. 
The paper also tests several other hypotheses from the literature. While in every case it is possible to see hints of these relationships in the results, none of these other relationships appears robust. Transition elections have a significant negative effect on tax collection in many of the specifications - and the effect is stronger when assuming a longer lag between fiscal effects and the elections themselves. ${ }^{19}$ However, we never find clear evidence that transition elections are statistically significantly different from all other elections. In various specifications there is evidence that unfree elections have a larger negative impact on tax collection, consistent with the view that pre-electoral fiscal manipulation is more likely in weak institutional environments. However, this result is variable across specifications, and highly dependent on how free and unfree elections are defined. Following the same logic, across virtually every specification the magnitude of the coefficient on first elections is substantially larger than for other elections. However, this effect never attains statistical significance at conventional levels. Finally, in two specifications there is evidence that elections disproportionately affect indirect taxes, but this does not hold true in the vast majority of cases. While the results here thus do not rule out these alternative hypotheses, they suggest that those relationships are at best relatively weak - while offering a reminder of the importance of high quality data, and detailed robustness testing.

The finding that competitive elections have led to a substantial decline in pre-election taxation is in some ways more striking precisely because of the weakness of all the other, equally plausible, results. In turn, this finding has important policy implications. The magnitude of the effect is estimated at 0.3 per cent to 0.5 per cent of GDP, and for countries struggling to raise sufficient revenue to fund public services and reduce aid dependence, this is a not insignificant hidden cost of competitive elections. Potentially more important than the revenue directly foregone in election years, however, is the possibility that the politicisation of tax enforcement prior to elections may have lingering effects on the probity, autonomy and effectiveness of revenue agencies. An important part of the early literature on political budget cycles in developing countries was motivated by the question of whether there may be a tension between elections and economic policy management and reform (Block 2002). The results here are clearly consistent with the existence of such a short-term trade-off, and point to the importance of countervailing measures to mitigate the risks of pre-election policy distortions.

Looking beyond the narrow realm of taxation, the results offer important insights into the ways that elections shape the incentives of political actors in developing countries - and, by extension, into the broader functioning of democracy. It is a foundational feature of democratic theory that elections should have a larger effect on political incentives when they are more competitive. However, in practice the importance of electoral competitiveness in developing countries has been relatively little studied, while many studies have continued to express some skepticism about whether elections of any kind are likely to have a significant impact on political incentives in low-income countries (e.g. van de Walle 2003).

For the most part, recent studies of elections in developing countries have continued to ask how multiparty elections in general affect development outcomes, with limited or no explicit attention to the competitiveness of those elections (e.g. Stasavage 2005; Harding and Stasavage 2014). An exception is the work of Chauvet and Collier (2009), who argue that elections only have a positive accountability effect when they are reasonable competitive. However, even Chauvet and Collier (2009) adopt only a very limited definition of competitiveness, which focuses on basic electoral freedoms and the opposition securing at least 25 per cent of the vote. The measure of competitiveness adopted here requires much more substantive competition, and correspondingly suggests that the impact of elections on

19 The latter is as we would expect: transition elections are particularly likely to generate post-election tax increases (Bates 1989; Ascher 1989), which is likely to obscure any negative relationship between elections and pre-election taxation when shorter lags are employed. 
political incentives is shaped not only by having broadly free and fair elections, but by having effective electoral challengers.

Of course, the results here focus on short-term pre-electoral incentives, and thus tell only a small part of any broader story about elections, electoral competitiveness and fiscal management. The results tell us unambiguously that competitive elections have a larger effect on short-term political incentives than do elections in general. In doing so they highlight the short-term cyclical costs associated with elections, and indicate that the short-term costs of elections are, perversely, greater when elections are more competitive. By contrast, the results do not say anything directly about long-term political incentives. However, it is only a small leap of reasoning to conclude that elections are equally likely to have a larger effect on long-term political incentives when they are competitive.

With this in mind, Chauvet and Collier (2009) draw a useful distinction between the shortterm cyclical effect of elections and the effect of elections on long-term political incentives. Critically, they argue that elections may simultaneously produce short-term costs, but substantially larger long-term gains. They find that the long-term effect of elections is greater, and more positive, when elections are more competitive - though, as noted before, they use a more limited definition of electoral competitiveness. The results here are consistent with this argument, while employing a more precise measure of competitiveness. While highlighting that electoral competitiveness amplifes the (negative) short-term incentive effects of elections, it is a natural extension of the finding to expect that competitive elections may similarly amplify the (positive) long-term incentive effects of elections.

Critically, this possibility is consistent with existing tax research. Timmons (2010) has found that over the long term democracy has a positive impact on tax collection. More precisely aligned with the findings here, Jibao and Prichard (2013) present evidence that in Sierra Leone local-level elections have both resulted in a short-term decline in local government tax collection and generated long-term incentives for revenue-enhancing tax reform - with the latter benefits larger where elections have been more competitive. The most interesting message from the results here thus lies not in the specific finding that competitive elections lead to short-term reductions in tax collection - though that finding is itself important - but in the implication that electoral competitiveness may more generally amplify the incentive effect associated with elections in developing countries.

\section{Conclusions}

The results presented here call into question the existence of unconditional political budget cycles in relation to taxation. Instead, they focus attention on the importance of electoral competitiveness as the key factor shaping whether elections impact pre-electoral tax collection. While this finding is highly intuitive, it is surprising novel: in a recent review of the literature on conditional budget cycles by de Haan and Klomp (2013), the role of electoral competitiveness goes almost unmentioned, beyond a brief footnote (footnote 3, p. 388). The most important studies to have produced evidence that the margin of electoral victory drives political budget cycles are Efthyvoulou's (2012) study of the European Union and Aidt et al.'s (2011) study of Portuguese municipalities. As noted earlier, Block et al. (2003) and Chauvet and Collier (2009) explore the impact of electoral competitiveness on policy outcomes in developing countries, but both have relied on very limited measures of competitiveness. The results here thus suggest the importance of much greater attention to the incentive effects of electoral competitiveness in developing countries, both in relation to political budget cycles and to political incentives and behaviour more broadly. 


\section{Appendix}

Table A1 Robustness checks: re-estimating key results including all countries

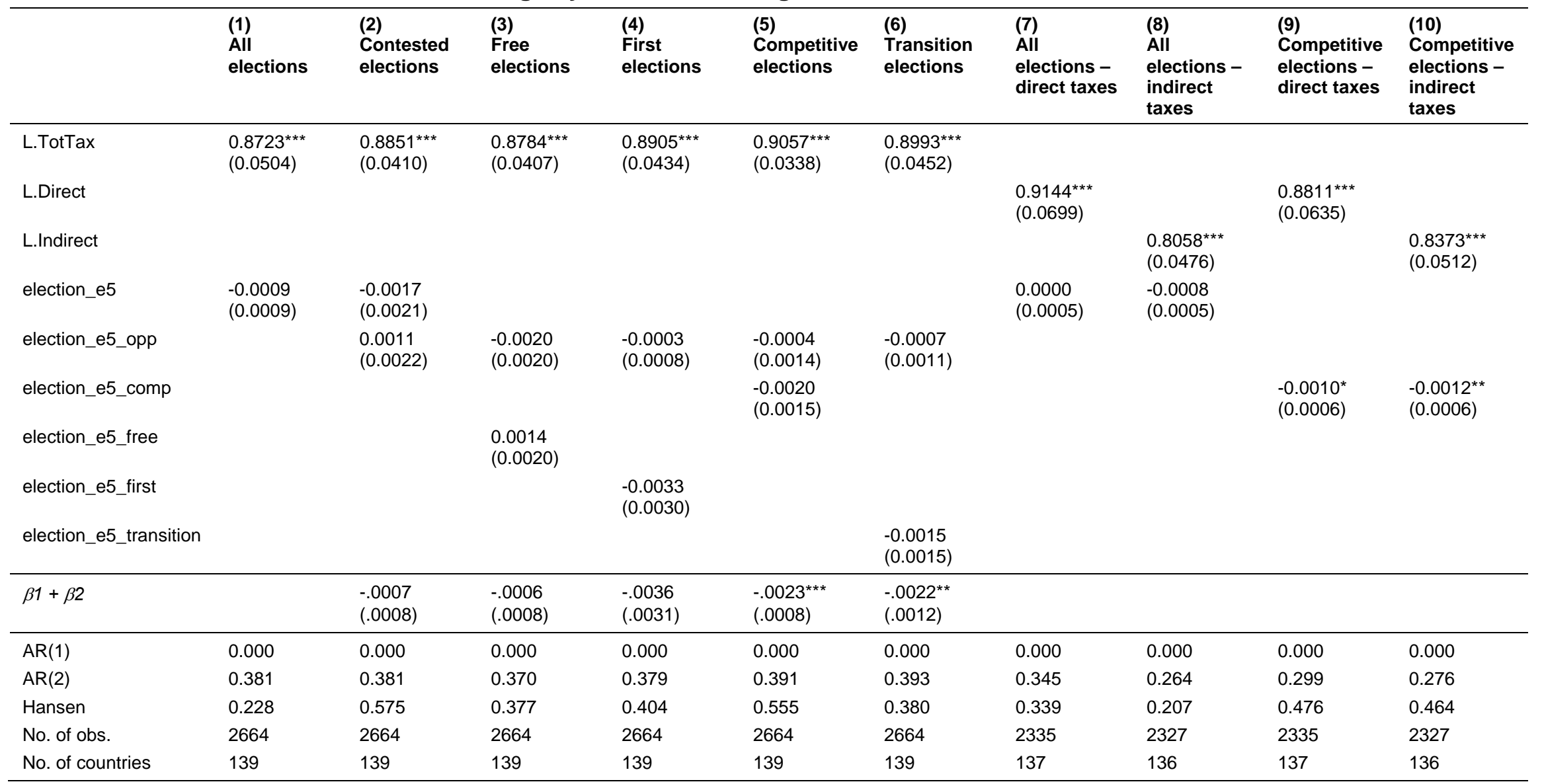

Notes: Standard errors in parentheses: ${ }^{*} p<0.10,{ }^{* *} p<0.05,{ }^{* \star *} p<0.01$. All results are based on the two-step System-GMM procedure with Windmeijer standard errors. The $p$-values reported for the Hansen statistic are for the null hypothesis that instruments are valid. The values reported for AR(2) are $\mathrm{p}$-values for tests of second order autocorrelation. The coefficients in row $\beta 1+\beta 2$ capture the total magnitude and significance of the impact of the subset of elections reflected in $\beta 2$. "All countries" includes every country for which data is available. Control variables Igdp, agric, imports,

civil_war, totnontax, inflation and growthpc are included in all regressions, but not reported in order to conserve space. 
Table A2 Robustness checks: re-estimating key results including all non-resource countries

\begin{tabular}{|c|c|c|c|c|c|c|c|c|c|c|}
\hline & $\begin{array}{l}\text { (1) } \\
\text { All } \\
\text { elections }\end{array}$ & $\begin{array}{l}\text { (2) } \\
\text { Contested } \\
\text { elections }\end{array}$ & $\begin{array}{l}\text { (3) } \\
\text { Free } \\
\text { elections }\end{array}$ & $\begin{array}{l}\text { (4) } \\
\text { First } \\
\text { elections }\end{array}$ & $\begin{array}{l}\text { (5) } \\
\text { Competitive } \\
\text { elections }\end{array}$ & $\begin{array}{l}\text { (6) } \\
\text { Transition } \\
\text { elections }\end{array}$ & $\begin{array}{l}\text { (7) } \\
\text { All } \\
\text { elections - } \\
\text { direct taxes }\end{array}$ & $\begin{array}{l}(8) \\
\text { All } \\
\text { elections - } \\
\text { indirect } \\
\text { taxes }\end{array}$ & $\begin{array}{l}\text { (9) } \\
\text { Competitive } \\
\text { elections - } \\
\text { direct taxes }\end{array}$ & $\begin{array}{l}(10) \\
\text { Competitive } \\
\text { elections - } \\
\text { indirect } \\
\text { taxes }\end{array}$ \\
\hline L.TotTax & $\begin{array}{l}0.8824^{\star \star \star} \\
(0.0467)\end{array}$ & $\begin{array}{l}0.8912^{\star \star \star} \\
(0.0424)\end{array}$ & $\begin{array}{l}0.8831^{\star *} \\
(0.3779)\end{array}$ & $\begin{array}{l}0.8926^{\star \star *} \\
(0.0767)\end{array}$ & $\begin{array}{l}0.9082^{\star \star \star} \\
(0.0350)\end{array}$ & $\begin{array}{l}0.8676^{\star \star *} \\
(0.0452)\end{array}$ & & & & \\
\hline L.Direct & & & & & & & $\begin{array}{l}0.9213^{\star \star \star} \\
(0.0694)\end{array}$ & & $\begin{array}{l}0.9079 \star \star \star \\
(0.0733)\end{array}$ & \\
\hline L.Indirect & & & & & & & & $\begin{array}{l}0.8464^{\star \star \star} \\
(0.0436)\end{array}$ & & $\begin{array}{l}0.8679^{\star \star \star} \\
(0.0396)\end{array}$ \\
\hline election_e5 & $\begin{array}{l}-0.0011 \\
(0.0009)\end{array}$ & $\begin{array}{l}-0.0026 \\
(0.0025)\end{array}$ & & & & & $\begin{array}{l}-0.0002 \\
(0.0005)\end{array}$ & $\begin{array}{l}-0.0009 \\
(0.0006)\end{array}$ & & \\
\hline election_e5_opp & & $\begin{array}{l}0.0013 \\
(0.0026)\end{array}$ & $\begin{array}{l}-0.0034 \\
(0.0344)\end{array}$ & $\begin{array}{l}-0.0009 \\
(0.0015)\end{array}$ & $\begin{array}{l}-0.0006 \\
(0.0014)\end{array}$ & $\begin{array}{l}-0.0010 \\
(0.0011)\end{array}$ & & & & \\
\hline election_e5_comp & & & & & $\begin{array}{l}-0.0012 \\
(0.0016)\end{array}$ & & & & $\begin{array}{l}-0.0012^{\star} \\
(0.0006)\end{array}$ & $\begin{array}{l}-0.0012^{\star \star} \\
(0.0006)\end{array}$ \\
\hline election_e5_free & & & $\begin{array}{l}0.0023 \\
(0.0327)\end{array}$ & & & & & & & \\
\hline election_e5_first & & & & $\begin{array}{l}-0.0032 \\
(0.0066)\end{array}$ & & & & & & \\
\hline election_e5_transition & & & & & & $\begin{array}{l}-0.0014 \\
(0.0017)\end{array}$ & & & & \\
\hline$\beta 1+\beta 2$ & & $\begin{array}{l}-.0012 \\
(.0008)\end{array}$ & $\begin{array}{l}-.0011 \\
(.0048)\end{array}$ & $\begin{array}{l}-.0040 \\
(.0062)\end{array}$ & $\begin{array}{l}-.0018^{* *} \\
(.0008)\end{array}$ & $\begin{array}{l}-.0023^{*} \\
(.0012)\end{array}$ & & & & \\
\hline $\mathrm{AR}(1)$ & 0.000 & 0.000 & 0.002 & 0.000 & 0.000 & 0.000 & 0.000 & 0.001 & 0.000 & 0.001 \\
\hline $\operatorname{AR}(2)$ & 0.339 & 0.341 & 0.390 & 0.332 & 0.348 & 0.344 & 0.510 & 0.247 & 0.434 & 0.258 \\
\hline Hansen & 0.109 & 0.489 & 0.338 & 0.481 & 0.530 & 0.362 & 0.227 & 0.195 & 0.356 & 0.581 \\
\hline No. of obs. & 2355 & 2355 & 2355 & 2355 & 2355 & 2355 & 2071 & 2061 & 2071 & 2061 \\
\hline No. of countries & 120 & 120 & 120 & 120 & 120 & 120 & 118 & 117 & 118 & 117 \\
\hline
\end{tabular}

Notes: Standard errors in parentheses: ${ }^{*} p<0.10,{ }^{* *} p<0.05,{ }^{* * *} p<0.01$. All results are based on the two-step System-GMM procedure with Windmeijer standard errors. The $p$-values reported for the Hansen statistic are for the null hypothesis that instruments are valid. The values reported for AR(2) are $p$-values for tests of second order autocorrelation. The coefficients in row $\beta 1+\beta 2$ capture the total magnitude and significance of the impact of the subset of elections reflected in $\beta 2$. Includes every country for which data is available except for major resource producers, which includes all the OPEC countries as well as countries that receive at least 15\% of GDP in non-tax revenue. Control variables lgdp, agric, imports, civil war, totnontax, inflation and growthpc are included in all

regressions, but not reported in order to conserve space. 
Table A3 Robustness checks: re-estimating key results including all non-resource developing countries

\begin{tabular}{|c|c|c|c|c|c|c|c|c|c|c|}
\hline & $\begin{array}{l}\text { (1) } \\
\text { All } \\
\text { elections }\end{array}$ & $\begin{array}{l}(2) \\
\text { Contested } \\
\text { elections }\end{array}$ & $\begin{array}{l}\text { (3) } \\
\text { Free } \\
\text { elections }\end{array}$ & $\begin{array}{l}\text { (4) } \\
\text { First } \\
\text { elections }\end{array}$ & $\begin{array}{l}\text { (5) } \\
\text { Competitive } \\
\text { elections }\end{array}$ & $\begin{array}{l}\text { (6) } \\
\text { Transition } \\
\text { elections }\end{array}$ & $\begin{array}{l}\text { (7) } \\
\text { All } \\
\text { elections - } \\
\text { direct taxes }\end{array}$ & $\begin{array}{l}\text { (8) } \\
\text { All } \\
\text { elections - } \\
\text { indirect } \\
\text { taxes }\end{array}$ & $\begin{array}{l}\text { (9) } \\
\text { Competitive } \\
\text { elections - } \\
\text { direct taxes }\end{array}$ & $\begin{array}{l}(10) \\
\text { Competitive } \\
\text { elections - } \\
\text { indirect } \\
\text { taxes }\end{array}$ \\
\hline L.Direct & & & & & & & $\begin{array}{l}0.8717^{\star * *} \\
(0.0615)\end{array}$ & & $\begin{array}{l}0.9012^{\star * *} \\
(0.0524)\end{array}$ & \\
\hline L.Indirect & & & & & & & & $\begin{array}{l}0.7222^{\star \star \star} \\
(0.0568)\end{array}$ & & $\begin{array}{l}0.7646^{\star \star \star} \\
(0.0665)\end{array}$ \\
\hline election_e5 & $\begin{array}{l}-0.0015 \\
(0.0012)\end{array}$ & $\begin{array}{l}-0.0005 \\
(0.0031)\end{array}$ & & & & & $\begin{array}{l}-0.0007 \\
(0.0006)\end{array}$ & $\begin{array}{l}-0.0007 \\
(0.0010)\end{array}$ & & \\
\hline election_e5_opp & & $\begin{array}{l}-0.0012 \\
(0.0035)\end{array}$ & $\begin{array}{l}-0.0027 \\
(0.0023)\end{array}$ & $\begin{array}{l}-0.0008 \\
(0.0012)\end{array}$ & $\begin{array}{l}-0.0005 \\
(0.0015)\end{array}$ & $\begin{array}{l}-0.0014 \\
(0.0014)\end{array}$ & & & & \\
\hline election_e5_comp & & & & & $\begin{array}{l}-0.0036^{*} \\
(0.0021)\end{array}$ & & & & $\begin{array}{l}-0.0008 \\
(0.0008)\end{array}$ & $\begin{array}{l}-0.0017^{*} \\
(0.0009)\end{array}$ \\
\hline election_e5_free & & & $\begin{array}{l}0.0028 \\
(0.0025)\end{array}$ & & & & & & & \\
\hline election_e5_first & & & & $\begin{array}{l}-0.0042 \\
(0.0034)\end{array}$ & & & & & & \\
\hline$\beta 1+\beta 2$ & & $\begin{array}{l}-.0018 \\
(.0013)\end{array}$ & $\begin{array}{l}.0001 \\
(.0015)\end{array}$ & $\begin{array}{l}-.0050 \\
(.0032)\end{array}$ & $\begin{array}{l}-.0040^{\star \star} \\
(.0017)\end{array}$ & $\begin{array}{l}-.0022 \\
.0015\end{array}$ & & & & \\
\hline $\mathrm{AR}(1)$ & 0.000 & 0.000 & 0.001 & 0.000 & 0.000 & 0.000 & 0.000 & 0.005 & 0.000 & 0.004 \\
\hline $\operatorname{AR}(2)$ & 0.305 & 0.293 & 0.324 & 0.287 & 0.300 & 0.286 & 0.955 & 0.260 & 0.876 & 0.253 \\
\hline Hansen & 0.609 & 0.998 & 1.000 & 1.000 & 1.000 & 1.000 & 0.850 & 0.750 & 0.940 & 0.992 \\
\hline No. of obs. & 1612 & 1612 & 1612 & 1612 & 1612 & 1612 & 1338 & 1327 & 1338 & 1327 \\
\hline No. of countries & 84 & 84 & 84 & 84 & 84 & 84 & 82 & 81 & 82 & 81 \\
\hline
\end{tabular}

Notes: Standard errors in parentheses: * $p<0.10,{ }^{* *} p<0.05,{ }^{* \star *} p<0.01$. All results are based on the two-step System-GMM procedure with Windmeijer standard errors. The $p$-values reported for the Hansen statistic are for the null hypothesis that instruments are valid. The values reported for AR(2) are $\mathrm{p}$-values for tests of second order autocorrelation. The coefficients in row $\beta 1+\beta 2$ capture the total magnitude and significance of the impact of the subset of elections reflected in $\beta 2$. Includes every developing country for which data is available except for major resource producers, which includes all the OPEC countries as well as countries that receive at least 15\% of GDP in non-tax revenue. Control variables lgdp, agric, imports, civil war, totnontax, inflation and growthpc are included in all regressions, but not reported in order to conserve space. 
Table A4 Robustness checks: re-estimating key results including all low-income countries

\begin{tabular}{|c|c|c|c|c|c|c|c|c|c|c|}
\hline & $\begin{array}{l}\text { (1) } \\
\text { All } \\
\text { elections }\end{array}$ & $\begin{array}{l}(2) \\
\text { Contested } \\
\text { elections }\end{array}$ & $\begin{array}{l}\text { (3) } \\
\text { Free } \\
\text { elections }\end{array}$ & $\begin{array}{l}\text { (4) } \\
\text { First } \\
\text { elections }\end{array}$ & $\begin{array}{l}\text { (5) } \\
\text { Competitive } \\
\text { elections }\end{array}$ & $\begin{array}{l}\text { (6) } \\
\text { Transition } \\
\text { elections }\end{array}$ & $\begin{array}{l}\text { (7) } \\
\text { All } \\
\text { elections - } \\
\text { direct taxes }\end{array}$ & $\begin{array}{l}\text { (8) } \\
\text { All } \\
\text { elections - } \\
\text { indirect } \\
\text { taxes }\end{array}$ & $\begin{array}{l}\text { (9) } \\
\text { Competitive } \\
\text { elections - } \\
\text { direct taxes }\end{array}$ & $\begin{array}{l}\text { (10) } \\
\text { Competitive } \\
\text { elections - } \\
\text { indirect } \\
\text { taxes }\end{array}$ \\
\hline L.TotTax & $\begin{array}{l}0.5152^{\star \star \star} \\
(0.1714)\end{array}$ & $\begin{array}{l}0.5938^{\star \star \star} \\
(0.1635)\end{array}$ & $\begin{array}{l}0.5897^{\star * \star} \\
(0.1871)\end{array}$ & $\begin{array}{l}0.6182^{\star \star \star} \\
(0.1192)\end{array}$ & $\begin{array}{l}0.5671^{\star \star \star} \\
(0.1654)\end{array}$ & $\begin{array}{l}0.6000^{\star \star \star} \\
(0.1354)\end{array}$ & & & & \\
\hline L.Direct & & & & & & & $\begin{array}{l}0.7449^{\star \star \star} \\
(0.1307)\end{array}$ & & $\begin{array}{l}0.8230^{\star \star \star} \\
(0.1374)\end{array}$ & \\
\hline L.Indirect & & & & & & & & $\begin{array}{l}0.6533^{\star \star \star} \\
(0.1427)\end{array}$ & & $\begin{array}{l}0.5655^{\star \star \star} \\
(0.0766)\end{array}$ \\
\hline election_e5 & $\begin{array}{l}-0.0000 \\
(0.0013)\end{array}$ & $\begin{array}{l}-0.0016 \\
(0.0031)\end{array}$ & & & & & $\begin{array}{l}-0.0001 \\
(0.0007)\end{array}$ & $\begin{array}{l}-0.0008 \\
(0.0010)\end{array}$ & & \\
\hline election_e5_opp & & $\begin{array}{l}0.0006 \\
(0.0033)\end{array}$ & $\begin{array}{l}-0.0032^{*} \\
(0.0017)\end{array}$ & $\begin{array}{l}-0.0008 \\
(0.0015)\end{array}$ & $\begin{array}{l}0.0002 \\
(0.0018)\end{array}$ & $\begin{array}{l}-0.0009 \\
(0.0015)\end{array}$ & & & & \\
\hline election_e5_comp & & & & & $\begin{array}{l}-0.0028 \\
(0.0028)\end{array}$ & & & & $\begin{array}{l}-0.0006 \\
(0.0010)\end{array}$ & $\begin{array}{l}0.0004 \\
(0.0010)\end{array}$ \\
\hline election_e5_free & & & $\begin{array}{l}0.0032 \\
(0.0022)\end{array}$ & & & & & & & \\
\hline election_e5_first & & & & $\begin{array}{l}-0.0043 \\
(0.0037)\end{array}$ & & & & & & \\
\hline election_e5_transition & & & & & & $\begin{array}{l}-0.0004 \\
(0.0021)\end{array}$ & & & & \\
\hline$\beta 1+\beta 2$ & & $\begin{array}{l}-.0010 \\
(.0011) \\
\end{array}$ & $\begin{array}{l}-.0000 \\
(.0016) \\
\end{array}$ & $\begin{array}{l}-.0050 \\
(.0035)\end{array}$ & $\begin{array}{l}-.0026 \\
(.0021)\end{array}$ & $\begin{array}{l}-.0013 \\
(.0015)\end{array}$ & & & & \\
\hline $\operatorname{AR}(1)$ & 0.017 & 0.008 & 0.015 & 0.002 & 0.006 & 0.003 & 0.001 & 0.016 & 0.000 & 0.029 \\
\hline $\mathrm{AR}(2)$ & 0.364 & 0.321 & 0.295 & 0.275 & 0.322 & 0.305 & 0.912 & 0.198 & 0.756 & 0.254 \\
\hline Hansen & 1.000 & 1.000 & 1.000 & 1.000 & 1.000 & 1.000 & 1.000 & 1.000 & 0.997 & 1.000 \\
\hline No. of obs. & 1239 & 1239 & 1239 & 1239 & 1239 & 1239 & 1001 & 991 & 1001 & 991 \\
\hline No. of countries & 62 & 62 & 62 & 62 & 62 & 62 & 61 & 60 & 61 & 60 \\
\hline
\end{tabular}

Notes: Standard errors in parentheses: ${ }^{*} p<0.10,{ }^{* \star} p<0.05,{ }^{* \star *} p<0.01$. All results are based on the two-step System-GMM procedure with Windmeijer standard errors. The $p$-values reported for the Hansen statistic are for the null hypothesis that instruments are valid. The values reported for AR(2) are $\mathrm{p}$-values for tests of second order autocorrelation. The coefficients in row $\beta 1+\beta 2$ capture the total magnitude and significance of the impact of the subset of elections reflected in $\beta 2$. Low-income countries includes all countries classified by the World Bank in 2008 as low-income or lower middle-income. Control variables Igdp, agric, imports, civil war, totnontax, inflation and growthpc are included in all regressions, but not reported in order to conserve space. 
Table A5 Robustness checks: re-estimating key results using same year definition of elections

\begin{tabular}{|c|c|c|c|c|c|c|c|c|c|c|}
\hline & $\begin{array}{l}\text { (1) } \\
\text { All } \\
\text { elections }\end{array}$ & $\begin{array}{l}\text { (2) } \\
\text { Contested } \\
\text { elections }\end{array}$ & $\begin{array}{l}\text { (3) } \\
\text { Free } \\
\text { elections }\end{array}$ & $\begin{array}{l}\text { (4) } \\
\text { First } \\
\text { elections }\end{array}$ & $\begin{array}{l}\text { (5) } \\
\text { Competitive } \\
\text { elections }\end{array}$ & $\begin{array}{l}\text { (6) } \\
\text { Transition } \\
\text { elections }\end{array}$ & $\begin{array}{l}\text { (7) } \\
\text { All } \\
\text { elections - } \\
\text { direct taxes }\end{array}$ & $\begin{array}{l}\text { (8) } \\
\text { All } \\
\text { elections - } \\
\text { indirect } \\
\text { taxes }\end{array}$ & $\begin{array}{l}\text { (9) } \\
\text { Competitive } \\
\text { elections - } \\
\text { direct taxes }\end{array}$ & $\begin{array}{l}(10) \\
\text { Competitive } \\
\text { elections - } \\
\text { indirect } \\
\text { taxes }\end{array}$ \\
\hline L.TotTax & $\begin{array}{l}0.7481^{\star \star *} \\
(0.0552)\end{array}$ & $\begin{array}{l}0.7409^{\star \star *} \\
(0.0517)\end{array}$ & $\begin{array}{l}0.7886^{\star * *} \\
(0.0493)\end{array}$ & $\begin{array}{l}0.6986^{\star \star *} \\
(0.0770)\end{array}$ & $\begin{array}{l}0.7599 * \star \star \\
(0.0608)\end{array}$ & $\begin{array}{l}0.7940 \text { *** } \\
(0.0552)\end{array}$ & & & & \\
\hline L.Direct & & & & & & & $\begin{array}{l}0.8430 * * * \\
(0.0610)\end{array}$ & & $\begin{array}{l}0.8382^{\star * \star} \\
(0.0471)\end{array}$ & \\
\hline L.Indirect & & & & & & & & $\begin{array}{l}0.6797^{\star \star \star} \\
(0.0625)\end{array}$ & & $\begin{array}{l}0.7209 \star \star \star \\
(0.0599)\end{array}$ \\
\hline election_e0 & $\begin{array}{l}-0.0007 \\
(0.0011)\end{array}$ & $\begin{array}{l}-0.0002 \\
(0.0019)\end{array}$ & & & & & $\begin{array}{l}0.0000 \\
(0.0005)\end{array}$ & $\begin{array}{l}-0.0008 \\
(0.0007)\end{array}$ & & \\
\hline election_e0_opp & & $\begin{array}{l}0.0001 \\
(0.0022)\end{array}$ & $\begin{array}{l}-0.0022 \\
(0.0021)\end{array}$ & $\begin{array}{l}-0.0005 \\
(0.0010)\end{array}$ & $\begin{array}{l}0.0004 \\
(0.0018)\end{array}$ & $\begin{array}{l}-0.0018 \\
(0.0013)\end{array}$ & & & & \\
\hline election_e0_comp & & & & & $\begin{array}{l}-0.0008 \\
(0.0021)\end{array}$ & & & & $\begin{array}{l}0.0001 \\
(0.0005)\end{array}$ & $\begin{array}{l}-0.0011 \\
(0.0009)\end{array}$ \\
\hline election_e0_free & & & $\begin{array}{l}0.0032 \\
(0.0022)\end{array}$ & & & & & & & \\
\hline election_e0_first & & & & $\begin{array}{l}0.0003 \\
(0.0029)\end{array}$ & & & & & & \\
\hline election_e0_transition & & & & & & $\begin{array}{l}0.0035^{\star} \\
(0.0021)\end{array}$ & & & & \\
\hline$\beta 1+\beta 2$ & & $\begin{array}{l}-.0000 \\
(.0012)\end{array}$ & $\begin{array}{l}.0010 \\
(.0012)\end{array}$ & $\begin{array}{l}-.0002 \\
(.0030)\end{array}$ & $\begin{array}{l}-.0004 \\
(.0011)\end{array}$ & $\begin{array}{l}.0017 \\
(.0018)\end{array}$ & & & & \\
\hline $\operatorname{AR}(1)$ & 0.000 & 0.000 & 0.000 & 0.000 & 0.000 & 0.000 & 0.000 & 0.002 & 0.000 & 0.002 \\
\hline $\operatorname{AR}(2)$ & 0.343 & 0.375 & 0.340 & 0.373 & 0.360 & 0.359 & 0.650 & 0.275 & 0.650 & 0.278 \\
\hline Hansen & 0.428 & 0.982 & 0.993 & 0.983 & 0.953 & 0.971 & 0.609 & 0.920 & 0.498 & 0.849 \\
\hline No. of obs. & 1870 & 1870 & 1870 & 1870 & 1870 & 1870 & 1551 & 1542 & 1551 & 1542 \\
\hline No. of countries & 98 & 98 & 98 & 98 & 98 & 98 & 96 & 95 & 96 & 95 \\
\hline
\end{tabular}

Notes: Standard errors in parentheses: ${ }^{*} p<0.10,{ }^{* *} p<0.05,{ }^{* \star} p<0.01$. All results are based on the two-step System-GMM procedure with Windmeijer standard errors. The $p$-values reported for the Hansen statistic are for the null hypothesis that instruments are valid. The values reported for AR(2) are $\mathrm{p}$-values for tests of second order autocorrelation. The coefficients in row $\beta 1+\beta 2$ capture the total magnitude and significance of the impact of the subset of elections reflected in $\beta 2$. Effective election year coded as the calendar year in which the election occurred. Control variables $l g d p$, agric, imports, civil_war, totnontax, inflation and growthpc are included in all regressions, but not reported in order to conserve space. 
Table A6 Robustness checks: re-estimating key results using E6 definition of elections

\begin{tabular}{|c|c|c|c|c|c|c|c|c|c|c|}
\hline & $\begin{array}{l}\text { (1) } \\
\text { All } \\
\text { elections }\end{array}$ & $\begin{array}{l}\text { (2) } \\
\text { Contested } \\
\text { elections }\end{array}$ & $\begin{array}{l}\text { (3) } \\
\text { Free } \\
\text { elections }\end{array}$ & $\begin{array}{l}\text { (4) } \\
\text { First } \\
\text { elections }\end{array}$ & $\begin{array}{l}\text { (5) } \\
\text { Competitive } \\
\text { elections }\end{array}$ & $\begin{array}{l}\text { (6) } \\
\text { Transition } \\
\text { elections }\end{array}$ & $\begin{array}{l}\text { (7) } \\
\text { All } \\
\text { elections - } \\
\text { direct taxes }\end{array}$ & $\begin{array}{l}\text { (8) } \\
\text { All } \\
\text { elections - } \\
\text { indirect } \\
\text { taxes }\end{array}$ & $\begin{array}{l}\text { (9) } \\
\text { Competitive } \\
\text { elections - } \\
\text { direct taxes }\end{array}$ & $\begin{array}{l}(10) \\
\text { Competitive } \\
\text { elections - } \\
\text { indirect } \\
\text { taxes }\end{array}$ \\
\hline L.Direct & & & & & & & $\begin{array}{l}0.8206^{* * *} \\
(0.0616)\end{array}$ & & $\begin{array}{l}0.8674^{\star * *} \\
(0.0505)\end{array}$ & \\
\hline L.Indirect & & & & & & & & $\begin{array}{l}0.7037^{\star \star \star} \\
(0.0666)\end{array}$ & & $\begin{array}{l}0.7299 * \star \star \\
(0.0649)\end{array}$ \\
\hline election_e6 & $\begin{array}{l}-0.0014 \\
(0.0010)\end{array}$ & $\begin{array}{l}0.0002 \\
(0.0018)\end{array}$ & & & & & $\begin{array}{l}-0.0008 \\
(0.0005)\end{array}$ & $\begin{array}{l}-0.0005 \\
(0.0008)\end{array}$ & & \\
\hline election_e6_opp & & $\begin{array}{l}-0.0019 \\
(0.0021)\end{array}$ & $\begin{array}{l}-0.0030 \\
(0.0023)\end{array}$ & $\begin{array}{l}-0.0018^{*} \\
(0.0011)\end{array}$ & $\begin{array}{l}-0.0004 \\
(0.0017)\end{array}$ & $\begin{array}{l}-0.0009 \\
(0.0013)\end{array}$ & & & & \\
\hline election_e6_comp & & & & & $\begin{array}{l}-0.0031 \\
(0.0022)\end{array}$ & & & & $\begin{array}{l}-0.0012^{*} \\
(0.0007)\end{array}$ & $\begin{array}{l}-0.0020^{* *} \\
(0.0009)\end{array}$ \\
\hline election_e6_free & & & $\begin{array}{l}0.0015 \\
(0.0024)\end{array}$ & & & & & & & \\
\hline election_e6_first & & & & $\begin{array}{l}-0.0014 \\
(0.0031)\end{array}$ & & & & & & \\
\hline election_e6_transition & & & & & & $\begin{array}{l}-0.0023 \\
(0.0020) \\
\end{array}$ & & & & \\
\hline$\beta 1+\beta 2$ & & $\begin{array}{l}-.0017 \\
(.0011) \\
\end{array}$ & $\begin{array}{l}-.0015 \\
(.0012) \\
\end{array}$ & $\begin{array}{l}-.0031 \\
(.0030) \\
\end{array}$ & $\begin{array}{l}-.0035^{\star \star} \\
(0.0014) \\
\end{array}$ & $\begin{array}{l}-.0032^{\star *} \\
(0.0016) \\
\end{array}$ & & & & \\
\hline$A R(1)$ & 0.000 & 0.000 & 0.000 & 0.000 & 0.000 & 0.000 & 0.000 & 0.001 & 0.000 & 0.002 \\
\hline $\mathrm{AR}(2)$ & 0.352 & 0.349 & 0.361 & 0.351 & 0.326 & 0.340 & 0.644 & 0.279 & 0.584 & 0.276 \\
\hline Hansen & 0.496 & 0.995 & 0.995 & 0.994 & 0.988 & 0.998 & 0.557 & 0.368 & 0.724 & 0.818 \\
\hline No. of obs. & 1870 & 1870 & 1870 & 1870 & 1870 & 1870 & 1551 & 1542 & 1551 & 1542 \\
\hline No. of countries & 98 & 98 & 98 & 98 & 98 & 98 & 96 & 95 & 96 & 95 \\
\hline
\end{tabular}

Notes: Standard errors in parentheses: * $p<0.10,{ }^{* *} p<0.05,{ }^{* \star *} p<0.01$. All results are based on the two-step System-GMM procedure with Windmeijer standard errors. The $p$-values reported for the Hansen statistic are for the null hypothesis that instruments are valid. The values reported for AR(2) are $\mathrm{p}$-values for tests of second order autocorrelation. The coefficients in row $\beta 1+\beta 2$ capture the total magnitude and significance of the impact of the subset of elections reflected in $\beta 2$. Effective election year coded as the calendar year in which the election took place if the election occurred during the last six months of the year, and coded as the year prior to the calendar year of the election if it occurred during the first six months of the calendar year. Control variables lgdp, agric, imports, civil_war, totnontax, inflation and growthpc are included in all regressions, but not reported in order to conserve space. 
Table A7 Robustness checks: re-estimating key results using E4 definition of elections

\begin{tabular}{|c|c|c|c|c|c|c|c|c|c|c|}
\hline & (1) & (2) & (3) & (4) & (5) & (6) & (7) & (8) & (9) & (10) \\
\hline & $\begin{array}{l}\text { All } \\
\text { elections }\end{array}$ & $\begin{array}{l}\text { Contested } \\
\text { elections }\end{array}$ & $\begin{array}{l}\text { Free } \\
\text { elections }\end{array}$ & $\begin{array}{l}\text { First } \\
\text { elections }\end{array}$ & $\begin{array}{l}\text { Competitive } \\
\text { elections }\end{array}$ & $\begin{array}{l}\text { Transition } \\
\text { elections }\end{array}$ & $\begin{array}{l}\text { All } \\
\text { elections - } \\
\text { direct taxes }\end{array}$ & $\begin{array}{l}\text { All } \\
\text { elections - } \\
\text { indirect } \\
\text { taxes }\end{array}$ & $\begin{array}{l}\text { Competitive } \\
\text { elections - } \\
\text { direct taxes }\end{array}$ & $\begin{array}{l}\text { Competitive } \\
\text { elections - } \\
\text { indirect } \\
\text { taxes }\end{array}$ \\
\hline L.TotTax & $\begin{array}{l}0.7608^{\star * *} \\
(0.0541)\end{array}$ & $\begin{array}{l}0.7435^{\star \star \star} \\
(0.0532)\end{array}$ & $\begin{array}{l}0.7683^{\star \star \star} \\
(0.0574)\end{array}$ & $\begin{array}{l}0.7928^{\star \star *} \\
(0.0755)\end{array}$ & $\begin{array}{l}0.7692^{\star \star *} \\
(0.0583)\end{array}$ & $\begin{array}{l}0.8066^{\star * *} \\
(0.0656)\end{array}$ & & & & \\
\hline L.Direct & & & & & & & $\begin{array}{l}0.8352^{\star * *} \\
(0.0639)\end{array}$ & & $\begin{array}{l}0.8524^{\star * *} \\
(0.0588)\end{array}$ & \\
\hline L.Indirect & & & & & & & & $\begin{array}{l}0.6726^{\star * \star} \\
(0.0702)\end{array}$ & & $\begin{array}{l}0.7423^{* \star *} \\
(0.0674)\end{array}$ \\
\hline election_e4 & $\begin{array}{l}-0.0015 \\
(0.0010)\end{array}$ & $\begin{array}{l}-0.0006 \\
(0.0020)\end{array}$ & & & & & $\begin{array}{l}-0.0004 \\
(0.0005)\end{array}$ & $\begin{array}{l}-0.0008 \\
(0.0008)\end{array}$ & & \\
\hline election_e4_opp & & $\begin{array}{l}-0.0004 \\
(0.0023)\end{array}$ & $\begin{array}{l}-0.0022 \\
(0.0019)\end{array}$ & $\begin{array}{l}-0.0013 \\
(0.0009)\end{array}$ & $\begin{array}{l}0.0010 \\
(0.0014)\end{array}$ & $\begin{array}{l}-0.0028^{*} \\
(0.0015)\end{array}$ & & & & \\
\hline election_e4_comp & & & & & $\begin{array}{l}-0.0051^{\star \star \star} \\
(0.0018)\end{array}$ & & & & $\begin{array}{l}-0.0010 \\
(0.0007)\end{array}$ & $\begin{array}{l}-0.0023^{\star *} \\
(0.0010)\end{array}$ \\
\hline election_e4_free & & & $\begin{array}{l}0.0013 \\
(0.0020)\end{array}$ & & & & & & & \\
\hline election_e4_first & & & & $\begin{array}{l}0.0016 \\
(0.0035)\end{array}$ & & & & & & \\
\hline election_e4_transition & & & & & & $\begin{array}{l}0.0021 \\
(0.0019)\end{array}$ & & & & \\
\hline$\beta 1+\beta 2$ & & $\begin{array}{l}-.0010 \\
(0.0010)\end{array}$ & $\begin{array}{l}-.0009 \\
(.0012)\end{array}$ & $\begin{array}{l}.0003 \\
(0.0035)\end{array}$ & $\begin{array}{l}-.0041^{\star \star \star} \\
(.0013)\end{array}$ & $\begin{array}{l}-.0007 \\
(.0014)\end{array}$ & & & & \\
\hline $\mathrm{AR}(1)$ & 0.000 & 0.000 & 0.000 & 0.000 & 0.000 & 0.000 & 0.000 & 0.002 & 0.000 & 0.001 \\
\hline $\operatorname{AR}(2)$ & 0.325 & 0.323 & 0.347 & 0.328 & 0.327 & 0.323 & 0.699 & 0.276 & 0.624 & 0.2640 .482 \\
\hline Hansen & 0.649 & 0.999 & 0.988 & 0.978 & 0.999 & 0.993 & 0.390 & 0.537 & 0.657 & \\
\hline No. of obs. & 1870 & 1870 & 1870 & 1870 & 1870 & 1870 & 1551 & 1542 & 1551 & 1542 \\
\hline No. of countries & 98 & 98 & 98 & 98 & 98 & 98 & 96 & 95 & 96 & 95 \\
\hline
\end{tabular}

Notes: Standard errors in parentheses: ${ }^{*} p<0.10,{ }^{* *} p<0.05,{ }^{* *} p<0.01$. All results are based on the two-step System-GMM procedure with Windmeijer standard errors. The $p$-values reported for the Hansen statistic are for the null hypothesis that instruments are valid. The values reported for AR(2) are $\mathrm{p}$-values for tests of second order autocorrelation. The coefficients in row $\beta 1+\beta 2$ capture the total magnitude and significance of the impact of the subset of elections reflected in $\beta 2$. Effective election year coded as the calendar year in which the election took place if the election occurred during the last eight months of the year, and coded as the year prior to the calendar year if it occurred during the first four months of the calendar year. Control variables lgdp, agric, imports,

civil war, totnontax, inflation and growthpc are included in all regressions, but not reported in order to conserve space. 
Table A8 Robustness checks: re-estimating key results using E3 definition of elections

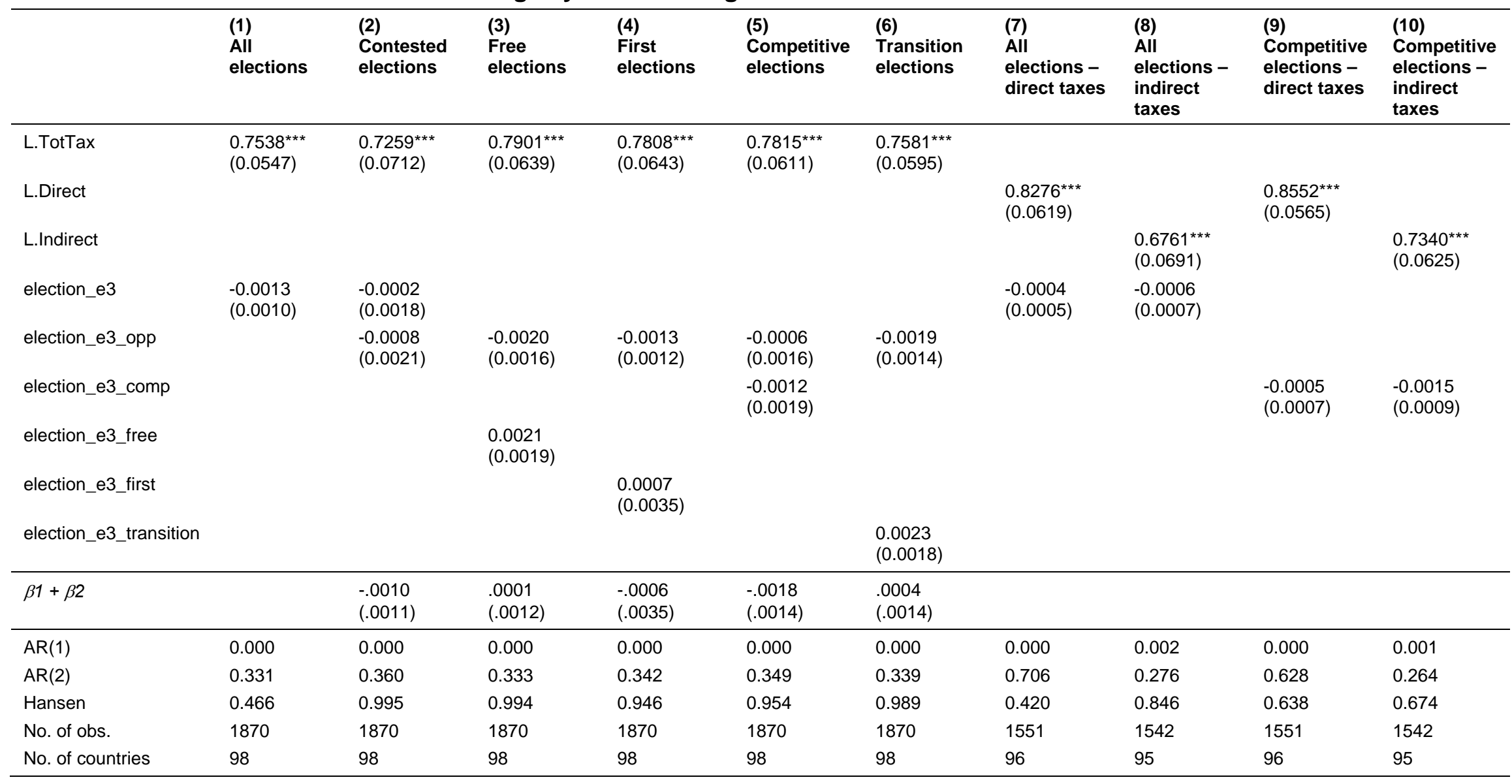

Notes: Standard errors in parentheses: ${ }^{*}<0.10,{ }^{*} p<0.05,{ }^{* \star} p<0.01$. All results are based on the two-step System-GMM procedure with Windmeijer standard errors. The $p$-values reported for the Hansen statistic are for the null hypothesis that instruments are valid. The values reported for AR(2) are $\mathrm{p}$-values for tests of second order autocorrelation. The coefficients in row $\beta 1+\beta 2$ capture the total magnitude and significance of the impact of the subset of elections reflected in $\beta 2$. Effective election year coded as the calendar year in which the election took place if the election occurred during the last nine months of the year, and coded as the year prior to the calendar year if it occurred during the first three months of the calendar year. Control variables lgdp, agric, imports, civil_war, totnontax, inflation and growthpc are included in all regressions, but not reported in order to conserve space. 


\section{References}

Aidt, T., Veiga, F. and Veiga, L. (2011) 'Election Results and Opportunistic Policies: A New Test of the Rational Political Business Cycle Model', Public Choice 148: 21-44

Ascher, W. (1989) 'Risk, Politics and Tax Reform: Lessons from Some Latin American Experiences', in M. Gillis (ed), Tax Reform in Developing Countries, Durham: Duke University Press

Ayee, J., Søreide, T., Shukla, G. and Le, T. (2011) Political Economy of the Mining Sector in Ghana, World Bank Policy Research Working Paper 5730, Washington DC: World Bank

Bates, R. (1989) 'A Political Scientist Looks at Tax Reform', in M. Gillis (ed), Tax Reform in Developing Countries, Durham NC: Duke University Press

Beck, T., Clarke, G., Groff, A., Keefer, P. and Walsh, P. (2001) 'New tools in comparative political economy: The Database of Political Institutions', World Bank Economic Review 15(1): 165-176

Benedek, D., Crivelli, E., Gupta, S. and Muthoora, P. (2012) Foreign Aid and Revenue: Still a Crowding Out Effect?, IMF Working Paper 12/186, Washington DC: International Monetary Fund

Bird, R. and Zolt, E. (2005) Redistribution via Taxation; The Limited Role of the Personal Income Tax in Developing Countries, International Tax Program Paper 0508, Toronto: Joseph L. Rotman School of Management

Bishop, S. and Hoefller, A. (2014) Free and Fair Elections - A New Database, CSAE Working Paper WPS/2014-14, Oxford: Centre for the Study of African Economies

Block, S. (2002) 'Political Business Cycles, Democratization and Economic Reform: The Case of Africa', Journal of Development Economics, 67(2): 205-228

_ Ferree, K., and Singh, S. (2003) 'Multiparty Competition, Founding Elections and Political Business Cycles in Africa', Journal of African Economies 12(3): 444-468

Blundell, R. and Bond, S. (1998) 'Initial conditions and moment restrictions in dynamic panel data models', Journal of Econometrics 87(1): 115-143

Bornhorst, F., Gupta, S. and Thornton, J. (2008) Natural Resource Endowments, Governance and the Domestic Revenue Effort: Evidence from a Panel of Countries, IMF Working Paper WP/08/170, Washington DC: International Monetary Fund

Brender, A. and Drazen, A. (2005) 'Political Budget Cycles in New Versus Established Democracies', Journal of Monetary Economics 52: 1271-1295

Chauvet, L. and Collier, P. (2009) 'Elections and Economic Policy in Developing Countries', Economic Policy 24: 509-50

de Haan, J. and Klomp, J. (2013) 'Conditional Political Budget Cycles: A Review of Recent Evidence', Public Choice 157: 387-410 
Drazen, A. (2001) 'The Political Business Cycles after 25 Years', in B. Bernanke and K. Rogoff (eds), NBER Macroeconomics Annals (pp. 75-117), Cambridge: MIT Press

_ and Eslava, M. (2010) 'Electoral Manipulation via Voter-Friendly Spending: Theory and Evidence', Journal of Development Economics 92(1): 39-52

Efthyvoulou, G. (2012) 'Political Budget Cycles in the European Union and the Impact of Political Pressures', Public Choice 153: 295-327

Erhart, H. (2013) 'Elections and the Structure of Taxation in Developing Countries', Public Choice 156(2): 195-211

Giliomee, H. and Simkins, C. (eds) (1999) The Awkward Embrace: One-Party Domination and Democracy, Amsterdam: Harwood Academic Publishers

Gordon, S. and Huber, G. (2007) 'The Effect of Electoral Competitiveness on Incumbent Behavior', Quarterly Journal of Political Science 2(2): 107-138

Harding, R. and Stasavage, D. (2014) 'What Democracy Does (and Doesn't Do) for Basic Services: School Fees, School Inputs and African Elections', The Journal of Politics 76(1): 229-245

Herrera, Y. and Kapur, D. (2007) 'Improving Data Quality: Actors, Incentives and Capabilities', Political Analysis 15: 365-386

Hyde, S. and Marinov, N. (2012) 'Which Elections can be Lost?', Political Analysis 20(2): 191-210

IMF, Article IV Staff Reports, <http://www.imf.org/external/ns/cs.aspx?id=51>

- Government Finance Statistics, <http://elibrarydata.imf.org/FindDataReports.aspx?d=33061\&e=170809>

Jerven, M. (2013) Poor Numbers: How We Are Misled by African Development Statistics and What To Do About It, Ithaca: Cornell University Press

Jibao, S. and Prichard, W. (2013) Rebuilding Local Government Finances After Conflict: The Political Economy of Property Taxation in Post-Conflict Sierra Leone, ICTD Working Paper 12, Brighton: International Centre for Tax and Development

Keen, M. and Mansour, M. (2009) Revenue Mobilization in Sub-Saharan Africa: Challenges from Globalization, IMF Working Paper 09/157, Washington DC: International Monetary Fund

Kelley, J. and Kolev, K. (2010) Election Quality and International Observation 1975-2004: Two New Datasets, Durham NC: Duke University

Kitschelt, H. and Wilkinson, S. (2007) 'Citizen-Politician Linkages: An Introduction', in H. Kitschelt and S. Wilkinson (eds), Patrons, Clients and Policies: Patterns of Democractic Accountability and Political Competition, Cambridge: Cambridge University Press

Marshall, M., Jaggers, K. and Gurr, T. (2012) Political regime characteristics and transitions, 1800-2008. Polity IV Project, Fairfax County: Center for Systemic Peace 
Martin, I. and Gabay, N. (2007) 'Do Visible Taxes Cause Protest? Tax Policy and Tax Protest in Rich Democracies', La Jolla, California: Department of Sociology, University of California-San Diego

Nickell, S. (1981) 'Biases in Dynamic Models with Fixed Effects', Econometrica 49: 14171426

Norhaus, W. (1975) 'The Political Business Cycle', Review of Economic Studies 42: 169-190

Osei, P. (2000) 'Political Liberalisation and the Implementation of Value Added Tax in Ghana', Journal of Modern African Studies 38: 255-78

Persson, T. and Tabellini, G. (2002) 'Do Electoral Cycles Differ across Political Systems?', Stockholm: IIES, Stockhom University

Prichard, W. (2010) Taxation, Responsiveness and Accountability in Sub-Saharan Africa, (DPhil), Brighton: University of Sussex

_ Cobham A. and Goodall A. (2014) The ICTD Government Revenue Dataset, ICTD Working Paper 19, Brighton: International Centre for Tax and Development

Rogoff, K. and Sibert, A. (1988) 'Elections and Macroeconomic Policy Cycles', Review of Economic Studies 55(1): 1-16

Roodman, D. (2009) 'A Note on the Theme of Too Many Instruments', Oxford Bulletin of Economics and Statistics 71(1): 135-158

- (2006) How to Do xtabond2: An Introduction to 'Difference' and 'System' GMM in Stata, Center for Global Development Working Paper Number 103, Washington DC: Center for Global Development

Schuknecht, L. (2000) 'Fiscal Policy Cycles and Public Expenditure in Developing Countries', Public Choice 102: 115-130

Shi, M. and Svensson, J. (2006) 'Political Budget Cycles: Do They Differ Across Countries and Why?', Journal of Public Economics 90: 1367-1389

Stasavage, D. (2005) 'Democracy and Education Spending in Africa', American Journal of Political Science 49(2): 343-358

Timmons, J. (2010) 'Taxation and Representation in Recent History', The Journal of Politics 72(1): 191-208

UCDP/PRIO, Armed Conflict Dataset, $<$ http://www.pcr.uu.se/research/ucdp/datasets/ucdp_prio_armed_conflict_dataset/>

van de Walle, N. (2003) 'Presidentialism and Clientelism in Africa's Emerging Party Systems', The Journal of Modern African Studies 41(2): 297-321

World Bank, World Development Indicators, <http://data.worldbank.org/data-catalog/worlddevelopment-indicators> 


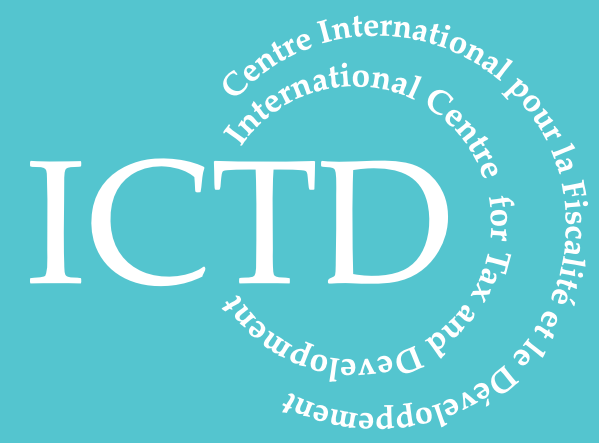

International Centre for Tax and Development at the Institute of Development Studies

Brighton BN1 9RE, UK

T: +44 (0) 1273606261

F: $+44(0) 1273621202$

E: info@ictd.ac

www.ictd.ac 